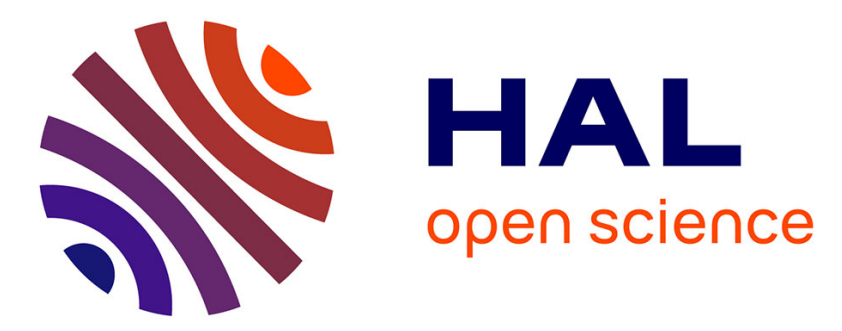

\title{
Hard core and cutting edge: experimental manufacture and use of Magdalenian composite projectile tips
}

\author{
Jean-Marc Pétillon, Olivier Bignon, Pierre Bodu, Pierre Cattelain, Gregory
}

Debout, Mathieu Langlais, Véronique Laroulandie, Hugues Plisson, Boris

Valentin

\section{To cite this version:}

Jean-Marc Pétillon, Olivier Bignon, Pierre Bodu, Pierre Cattelain, Gregory Debout, et al.. Hard core and cutting edge: experimental manufacture and use of Magdalenian composite projectile tips. Journal of Archaeological Science, 2011, 38 (6), pp.1266-1283. 10.1016/j.jas.2011.01.002 . halshs-00598540

\section{HAL Id: halshs-00598540 \\ https://shs.hal.science/halshs-00598540}

Submitted on 6 Jun 2011

HAL is a multi-disciplinary open access archive for the deposit and dissemination of scientific research documents, whether they are published or not. The documents may come from teaching and research institutions in France or abroad, or from public or private research centers.
L'archive ouverte pluridisciplinaire HAL, est destinée au dépôt et à la diffusion de documents scientifiques de niveau recherche, publiés ou non, émanant des établissements d'enseignement et de recherche français ou étrangers, des laboratoires publics ou privés. 


\title{
Hard core and cutting edge: experimental manufacture and use of Magdalenian composite projectile tips
}

\author{
Jean-Marc Pétillon ${ }^{\mathrm{a}}$, Olivier Bignon ${ }^{\mathrm{b}}$, Pierre Bodu ${ }^{\mathrm{b}}$, Pierre Cattelain ${ }^{\mathrm{c}, \mathrm{d}}$, Grégory Debout ${ }^{\mathrm{e}}$, \\ Mathieu Langlais ${ }^{\mathrm{f}}$, Véronique Laroulandie ${ }^{\mathrm{f}}$, Hugues Plisson ${ }^{\mathrm{f}}$, Boris Valentin ${ }^{\mathrm{g}}$
}

Journal of Archaeological Science, 38, 1266-1283.

http://dx.doi.org/10.1016/j.jas.2011.01.002

\footnotetext{
${ }^{\text {a }}$ CNRS, Laboratoire TRACES, Université Toulouse 2, Maison de la Recherche, 5 allées A. Machado, F-31058 Toulouse, France, petillon@univ-tlse2.fr

${ }^{\mathrm{b}}$ CNRS, Laboratoire ArScAn (Ethnologie Préhistorique), Maison René Ginouvès, 21 allée de l'Université, F92023 Nanterre, France, olivier.bignon@mae.uparis10.fr, pierre.bodu@mae.u-paris10.fr

${ }^{\mathrm{c}}$ Cedarc/Musée du Malgré-Tout, 28 rue de la Gare, B-5670 Treignes, Belgium, pierre.cattelain@ulb.ac.be

${ }^{\mathrm{d}}$ CRéA-Patrimoine, Université Libre de Bruxelles, Belgium

e Service archéologique des Yvelines, Laboratoire ArScAn (Ethnologie Préhistorique), Maison René Ginouvès, 21 allée de l'Université, F-92023 Nanterre, France, gregory.debout@mae.u-paris10.fr

${ }^{\mathrm{f}}$ CNRS, Laboratoire PACEA, Université Bordeaux 1, avenue des Facultés B18, F-33405 Talence, France, m.langlais@pacea.u-bordeaux1.fr,v.laroulandie@pacea.u-bordeaux1.fr,h.plisson@pacea.u-bordeaux1.fr

${ }^{\mathrm{g}}$ Université Paris I, Laboratoire ArScAn (Ethnologie Préhistorique), Institut d'Art et d'Archéologie, 3 rue Michelet, F-75006 Paris, France, valentin@univ-paris1.fr
}

\section{Keywords}

Upper Palaeolithic, Magdalenian, Pincevent, Experimental archaeology, Hunting, Composite projectile head, Flint backed bladelet

\begin{abstract}
The technology of the European Upper Palaeolithic yielded abundant evidence of the use of composite projectile heads, in the form of osseous points on the side of which one or several (micro)lithic elements are attached. Yet, little experimental work has been devoted to testing and assessing the parameters of use of this type of composite tips. In this paper we present a pilot experiment with replicas of Magdalenian composite spear tips, made of an antler point with one or two rows of flint backed bladelets. Two series of replicas were manufactured after the lithic and osseous record of, respectively, the Lower Magdalenian from southwest France (c. 20-18 Ky cal BP) and the Upper Magdalenian of Pincevent in the Paris Basin (c. 15-14 Ky cal BP). The 34 experimental composite heads were hafted to spears that were then shot with a spearthrower at the carcasses of two young deer. The results provide some insight into the performance characteristics of the osseous and lithic components, both in efficiency and durability. Finally, possible improvements of the experimental protocol are discussed, as well as the implications of our results for the understanding of projectile point variability in the Upper Palaeolithic.
\end{abstract}

\section{Introduction}

The lithic and osseous industries of the European Upper Paleolithic (UP) are marked by the development of very numerous and diverse types of projectile tips. This trend is strong enough to justify the characterization of weaponry as "the most dynamic component of the Upper Paleolithic technologies" (Straus, 1993: p. 83; see also Straus, 2000: p. 42-43). Many UP archeological cultures are defined to a large extent by the specific morphology and manufacturing techniques of their lithic and/or osseous projectile tips (e.g., Elston and Kuhn, 2002). All these implements represent different technical solutions to ensure the capture of 
game, and thus are key elements in the discussion of hunter-gatherer interactions with the environment of Glacial Europe. For this reason, since the large development of experimental archeology in the years 1980, much work has been devoted to understanding the parameters of use, performance, and use-wear patterns of UP projectile points (Knecht, 1997a). Experimentation included the controlled replication and use of such varied types as Aurignacian split-based points (Knecht, 1993), Gravettian backed points (Borgia, 2008; Cattelain and Perpère, 1993, 1996; O'Farrell, 1996, 2004; Soriano, 1998) and Font-Robert points (Lansac, 2004), Solutrean shouldered points and tanged points (Geneste and Plisson, 1993; Márquez and Muñoz, 2008), several types of Magdalenian osseous points (Arndt and Newcomer, 1986; Pétillon, 2006; Pokines, 1998; Stodiek, 1993, 2000) and Azilian flint points (Plisson, 2005).

Much less projectile use experimentation, however, has been devoted to composite tips. In this article, this term refers to projectile heads consisting of a point made of osseous material (antler, bone or ivory), on the side of which one or several (micro) lithic elements are attached (Bergman, 1993: p. 99; Nuzhnyj, 1989, 2000, 2007). These implements are probably one of the most common categories of UP projectile heads. Indeed, osseous projectile points are found throughout the European UP (Delporte et al., 1988), and many of them show a longitudinal groove which is interpreted as a housing for lithic inserts (Allain and Rigaud, 1986; Bosinski, 2010; Houmard, 2003; Houmard and Jacquot, 2009) - this interpretation being based on analogies with similar osseous points from the Mesolithic of central Europe, north Europe and Russia that were found with flint elements still in place (Fig. 1). As for the lithic component, the importance of retouched flint bladelets in UP lithic kits has recently been reevaluated thanks to the widespread use of fine screening in modern excavations, and detailed studies of raw material choice and production sequences have revealed their significance as socioeconomic and territorial indicators (Bon, 2002; Bordes, 2002; Klaric et al., 2002; Langlais, 2010; Tiffagom, 2006; Valentin, 1995, 2008). Systematic flint bladelet production is now considered one of the markers of the beginning of the European UP (e.g., Bon, 2005) and it continues during this period without interruption, several cultures placing a particular emphasis on it (e.g., Le Brun-Ricalens et al., 2005). The usual interpretation of retouched bladelets is that of projectile elements fixed on the side of osseous points; this hypothesis is supported by traceological results (e.g., Christensen and Valentin, 2004; González and Ibáñez, 1993; Ibáñez et al., 1993; Keeley, 1988; Moss, 1983; O’Farrell, 2005; Pelegrin and O'Farrell, 2005; Plisson, 1985; Plisson and Vaughan, 2002; Symens, 1986) and by rare finds of lithic elements still hafted to a fragment of antler point (Allain and Descouts, 1957; Leroi-Gourhan, 1983; Nuzhnyj, 1993; Owen, 1987). Clearly, although their osseous and lithic components are almost always found disassembled in archaeological contexts, composite tips were of widespread use in the European UP.

In the few existing projectile experiments with laterally-hafted UP bladelets, the flint artifacts were set directly on the side of pointed wooden arrow shafts (Moss, 1983; Moss and Newcomer, 1982), or hafted as "barbs" on flint-tipped projectiles (Crombé et al., 2001). Almost all projectile experiments with osseous points involved only projectile heads without flint bladelets (see survey in Pétillon, 2006). Except for one exploratory study (Stodiek, 1993, 2000) and the experiments of Nuzhnyj (2007), there is no published account of a significant sample of osseous points with lithic inserts used under controlled experimental conditions. Ethnographic evidence suggests that these composite projectile tips allowed UP hunters to combine the qualities of the two materials: the sharpness of flint and the higher impact resistance of osseous materials (Knecht, 1997b; Ellis, 1997). But given the scarcity of experimental data, the actual performance and properties of composite tips remain largely speculative.

In this perspective, the authors organized an experimental projectile session held in February 
2008 at the Cedarc/Musée du Malgré-Tout (Treignes, Belgium). The purposes of this pilot experiment were twofold: assess the performance of the composite tips, both in efficiency and in durability; and generate a sample of characteristic traces (impact fractures, notably) on the lithic elements, the osseous points and the bones of the animals used as targets. Preliminary results were discussed during a seminar in March 2009 (Pétillon, 2009). The detailed traceological analysis is still under way. The remaining results are presented and discussed here.

\section{Archaeological references}

In order to manufacture plausible reconstructions of composite tips, it was necessary to select archaeological situations where a precisely characterized assemblage of flint bladelets could be associated with a well-documented assemblage of osseous points. This association had to be close enough to strongly suggest the combined use of the two components. Partly based on previous work of some of the authors (see 2.1. and 2.2.), two cases were chosen, both from the Magdalenian culture.

\subsection{The Lower Magdalenian from southwest France}

In southwest France, north of the Pyrenees, recent research in lithic technology led to the identification of a Lower Magdalenian phase, dated to the last part of the LGM (c. 20-18 Ky cal BP), different from both the preceding Badegoulian and the more recent Middle Magdalenian (Cazals, 2000; Ducasse and Langlais, 2007; Langlais, 2010; Le Brun-Ricalens and Brou, 2003; Primault et al., 2007). Lower Magdalenian lithic assemblages are characterized by an abundant production of microliths (the word "microlith" being used here in the strict sense of: armatures made on bladelets or micro-bladelets). Several of these assemblages yield a single population of retouched microlith: a bladelet or microbladelet with marginal backing on the right side opposite a sharp convex edge (Fig. 2). This is the situation at Scilles (Haute-Garonne; Langlais et al., 2010), Petit-Cloup-Barrat (Lot), Saint-Germain-laRivière level 3-4 (Gironde; Langlais, 2010) and Lascaux (Allain, 1979; Langlais, under study). Other assemblages yield two distinct groups: a population of backed micro-bladelets, and a population of backed bladelets and shouldered points which represent a different economic objective (Fig. 2). This is the case at Montlleó (Catalonia; Langlais and Mangado, 2007), Fontgrasse (Gard; Bazile et al., 1989) and Gandil level 20 (Tarn-et-Garonne; Langlais et al., 2007). The micro-bladelets vary from 3 to $5 \mathrm{~mm}$ in width, $1-2 \mathrm{~mm}$ in thickness and 8-25 $\mathrm{mm}$ in length, and often show a curved or twisted profile. The backed bladelets and points have a straight profile and are larger, reaching up to $50 \mathrm{~mm}$ long.

So far, observation of wear traces on the Lower Magdalenian microliths has been mainly qualitative. Macroscopic impact fractures have been documented on several of them, suggesting their use as side-hafted projectile elements (Langlais, 2010: observations at Gandil, Montlleó and Saint-Germain-la-Rivière). This idea is supported by several microliths from Lascaux, found in a context related to the initial phases of the Magdalenian, and whose retouched edge still bear traces of hafting adhesive with the negative imprint of the point (Allain, 1979).

Several collections of osseous points from Lower Magdalenian contexts have been recently studied: Gandil (Ladier in Langlais et al., 2007), Scilles (Pétillon in Langlais et al., 2010), Saint-Germain-la-Rivière (Pétillon, under study) and Lascaux (Leroy-Prost, 2008). These points are manufactured exclusively from reindeer antler. Almost all of them have a "massive" base, i.e., conical or spatulate in shape, with no bevel (Fig. 3); one of the Lascaux points shows traces of hafting on the proximal part (Leroy-Prost, 2008). Gandil also yielded 
two self-barbed points (as defined in Pokines and Krupa, 1997), and the assemblage at Scilles includes two single-beveled points (Pétillon in Langlais et al., 2010). The Lower Magdalenian points almost always show a rounded cross-section (oval or circular). Their dimensions are highly variable: at Scilles and Lascaux, several specimens reach 11-15 mm in width, 9-11 mm in thickness and 230-450 mm in length, which implies the use of very large antlers as raw material (Fig. 3); conversely, at Saint-Germain-la-Rivière, Gandil but also at Lascaux, many points show much smaller dimensions $-6-9 \mathrm{~mm}$ in width, 5-8 $\mathrm{mm}$ in thickness and 70-150 $\mathrm{mm}$ in length (Fig. 3). A minority of points (17\% at Scilles and Saint-Germain-la-Rivière) show longitudinal grooves probably used to hold microliths.

\subsection{The Upper Magdalenian from the Paris Basin: Pincevent-IV20}

The open-air site of Pincevent (Seine-et-Marne) yielded a succession of several occupations attributed to the Upper Magdalenian, and radiocarbon-dated to the Bølling chronozone (c. 1514 Ky cal BP: David and Orliac, 1994; Valladas, 1994). Most of the Magdalenian levels are fall occupations related to the hunting of migrating reindeer groups (David, 1994; Enloe and David, 1997). Level IV20, one of the top levels in the stratigraphy, has been made famous by the publication of Section 36 (Leroi-Gourhan and Brézillon, 1972) and is now one of the most extensively excavated levels at this site (over 5000 square meters). It was chosen as archaeological reference because it yielded $40 \%$ of the osseous projectile points known in the Upper Magdalenian of the Paris Basin, along with c. 600 retouched flint microliths, including the two specimens found attached to a fragment of antler point (Leroi-Gourhan, 1983).

The microlithic assemblage of level IV20 (Fig. 4) is made of backed bladelets with variable widths (4-8 mm), a thin profile (thickness: 1-2 mm) and lengths of 40-70 $\mathrm{mm}$. Their retouched back is straight in outline and profile. This back is generally made by direct retouch, but inverse retouch is present on $20-30 \%$ of the artifacts, which might be due to a specific effort to straighten the back on slightly curved blanks (Valentin, 1995: p. 411-424; see also Bodu, 1993; Debout, 2003). Traceological evidence indicates the probable use of the backed bladelets as projectile elements mounted on the side of the haft (Moss, 1983; Moss and Newcomer, 1982; Plisson, unpublished data quoted in Valentin, 1995: p. 427).

Nineteen osseous points and fragments have been recovered from level IV20 (Averbouh and Julien, 2004; David, 1972; Leroi- Gourhan and Brézillon, 1972: p. 204-205; Pétillon, 2008). All are made of reindeer antler. The 10 specimens whose proximal part is preserved show a double-beveled base, 23-36 mm long (Fig. 5). All the points have a quadrangular crosssection, and the large majority of them are of large dimensions: $10-12 \mathrm{~mm}$ in width, $6-9 \mathrm{~mm}$ in thickness, and between 150 and $200 \mathrm{~mm}$ in estimated length (none of these points is complete, but the three almost complete specimens reach 146, 166 and $191 \mathrm{~mm}$ ). A single complete specimen attests to the existence of a smaller category of double-beveled point (Fig. 5: width $7 \mathrm{~mm}$, thickness $5 \mathrm{~mm}$, length $70 \mathrm{~mm}$ ); a mesial fragment of similarly small caliber ( $6 \times 5 \mathrm{~mm}$ ) could belong to a second point of the same sub-type. Eight of the 11 points with a preserved mesial part show longitudinal grooves on one side ( 5 specimens) or both sides (3 specimens); these grooves vary in width from 1.5 to $4 \mathrm{~mm}$ and are always shallow (maximum depth $\approx 1 \mathrm{~mm}$ ). Here again, the usual interpretation of these grooves is as hafting slots for lithic elements. A small point fragment was found with two such elements still in place (Fig. $5)$.

\section{Experimental protocol}

\subsection{Manufacture of the projectile tips}




\subsubsection{The antler points}

Thirty-four points were manufactured from the main beam and the brow tine of five reindeer antlers. The antlers were from male individuals and were obtained from a domestic herd in northern Finland $(n=2)$ and from a mountain farm in the French Alps $(n=3)$. In an effort to spare time and material, most of the blanks were extracted with a hacksaw, and the blanks were then worked by scraping with flint burins. An average of $140 \mathrm{~min}$ was necessary to shape each blank into a finished point.

The types and dimensions of the points were chosen to reproduce the variability of the Lower Magdalenian points - including four specimens of simple-beveled points - and the variability of the double-beveled points of Pincevent-IV20 (Table 1; Fig. 6). However, the antlers used as raw material were not large enough to allow the replication of the longest points from the Lower Magdalenian (lengths above $230 \mathrm{~mm}$ ).

Since longitudinal grooves are rare on the Lower Magdalenian points with massive bases, none of the 12 experimental specimens were given such features. A short slot was carved on the upper side of the four single-beveled points, replicating one similar point from Scilles. Similarly, since almost all the points from Pincevent-IV20 have at least one long longitudinal groove, all 18 experimental points were made with a slot on the upper side $(n=9)$ or on both upper and lower sides $(n=9)$.

\subsubsection{The retouched microliths}

The replicas of the Lower Magdalenian microliths were made with flint from the Cher valley. Their dimensions were calibrated according to the "single population" model (Fig. 2): the 43 specimens include bladelets and micro-bladelets with a continuous range of lengths from 13 to $41 \mathrm{~mm}$ (Table 2). Twenty-seven specimens were hafted to the points at the beginning of the experiment, and the remaining 16 were used as spares during the shooting session (see 3.3).

One hundred replicas of the Pincevent-IV20 backed bladelets were manufactured with flint from the Paris Basin (Secondary flint from the Seine and Yonne valleys and Tertiary flint from outcrops near Seine-et-Marne and Oise). The total manufacturing time reached several hours because of the retouch work (at least 1 min was necessary to shape each back) and the high rate of breakage at this stage of the process. Among the 100 bladelets, 51 were selected for hafting to the antler points and the others were kept as spares, seven of which were used during the experiment (see 3.3). The dimensions of the 58 specimens reflect those of the archaeological sample (Table 2), although five of them (8.6\%) are $4 \mathrm{~mm}$ thick, slightly thicker than the backed bladelets from level IV20. On all the selected bladelets, the back was made by direct retouch: backs made by inverse retouch (20-30\% of the archaeological sample, see 2.2) are not represented in the experimental set. It is unlikely, however, that these minor discrepancies between the archaeological and experimental series influenced the results of the experiment.

\subsubsection{Mounting the microliths}

Since one of our objectives was to test the role and efficiency of the lithic inserts, 10 points (4 of Lower Magdalenian design and 6 of Upper Magdalenian design) were left "bare" - i.e., without microliths - in order to provide comparison data. The remaining 24 points were equipped with one or two rows of 1-4 microliths, the total number of microliths per point varying from 1 to 8 (Table 3 ).

All microliths were fixed with the retouched back against the side of the point. When several microliths were set on the same side, they were arranged in a continuous row, without spacing 
(Fig. 7). Two types of adhesive were used on 12 points each. The first type was a mixture of beeswax, resin and ochre. This recipe is similar to the one used for point hafting in several other projectile experiments (Arndt and Newcomer, 1986; Bergman,1987; Cattelain and Perpère, 1993, 1996; O'Farrell, 1996, 2004; Stodiek, 2000; etc.); it is compatible with the known evidence of the use of ochre and resin in Palaeolithic adhesives (Allain and Rigaud, 1989; Audouin and Plisson, 1982; Lombard, 2005, 2007; Wadley, 2005, 2006). The second type of adhesive was birch-bark pitch, whose use is widely attested from the Mesolithic onwards (Aveling and Heron, 1999) but was recently documented as early as the Middle Palaeolithic (Grünberg, 2002; Koller et al., 2001; Mazza et al., 2006) and the Aurignacian (Dinnis et al., 2009).

On the Lower Magdalenian points, the microliths were ranked according to size: the "head bladelet" (the one closest to the tip of the point) was always chosen among the smaller microliths, and the larger ones were set towards the base (second and third ranks). Considering that the curved profile of the bladelets might hamper their hafting in a file, we chose to arrange them head-to-tail, creating a sinuous cutting edge (Fig. 8).

On the Pincevent-IV20 points, the microliths were set according to the outline of their cutting edge: most of the microliths selected as head bladelets had a naturally curved sharp edge and pointed distal end, in order to optimize penetration (Fig. 7). When mounting the microliths on the replicas of the Pincevent-IV20 points, it soon appeared that the grooves on the points were too shallow $(0.5-1 \mathrm{~mm})$ to hold the backed bladelets in place. However, these grooves did facilitate the application of the adhesive: they acted as a gutter and prevented the mastic from slipping on the sides of the point. This statement suggests that at least some of the longitudinal grooves on UP osseous points might be regarded as aids for mastic application rather than "holders" for the retouched back of the lithic elements.

\subsection{The projectiles and their delivery mode}

On a purely morphometric basis, it is often difficult to classify UP points as either arrowheads or tips of spearthrower-propelled projectiles, as there is a dimensional overlap between the two categories and many UP points fall within the metric range of artifacts that could have been used to tip both types of projectiles (Cattelain, 1997; Hughes, 1998; Lansac, 2004; but see Riede, 2009, 2010 for a case where such an identification might be possible). Here, however, a probable diagnosis could be achieved for the majority of the sample. After analyzing several collections of ethnographic spears and arrows from Africa, Australia and the Americas, Cattelain concluded that spears (launched with a spearthrower) almost always have a larger diameter than arrows: for arrows, most values fall around 8-9 mm, while the mean diameter for spears lies c. 13-14 mm. Similarly, spear points are almost always heavier than arrow points, although there seems to be an overlap for values between 5 and $15 \mathrm{~g}$ (Cattelain, 1997: p. 229). Of our 34 experimental antler point replicas, 20 belong to large types with a mean width above $11 \mathrm{~mm}$ and a mean weight above $15 \mathrm{~g}$ (Table 1). Once equipped with lithic inserts, five of the composite tips weigh $30 \mathrm{~g}$ or more. These values are clearly above the range of arrowheads: hafting those tips to common arrow shafts would have made the projectiles impossible to balance (Cattelain, 1997; Rozoy, 1992). This suggests the use of larger, spear-like projectiles.

This hypothesis is in accordance with the direct archaeological evidence of spearthrower use in the Magdalenian. At El Mirón level 17, an antler spearthrower hook was found in a context contemporary with the end of the Lower Magdalenian in southwest France (González Morales and Straus, 2009). Most of the other UP spearthrower hooks were recovered either from ancient excavations with little or no stratigraphic information, or from Middle Magdalenian deposits. With a few exceptions, the available 14C dates show a chronological distribution c. 
15-13 kyrs BP or 18-15 kyrs cal BP (Cattelain, 2004, 2005; Riede, 2010, Fig. 4). At Isturitz, a spearthrower hook was recently dated by AMS to $12245 \pm 60 \mathrm{BP}$ or $14400-13920$ cal BP (OxA-19837), contemporary with the Upper Magdalenian (Szmidt et al., 2009).

Thus, contrary to what was made in a previous experiment with Magdalenian antler points (Letourneux and Pétillon, 2008; Pétillon, 2005, 2006), it was decided to haft all the points on spears launched with a spearthrower. The spear shafts were commercial dowels made of tropical light hardwood (meranti). They were $2700 \mathrm{~mm}$ long, $14 \mathrm{~mm}$ in diameter, weighed 150-200 $\mathrm{g}$ and were fletched with three radial feathers, $200-250 \mathrm{~mm}$ long. The distal end of the shafts was carved according to the shape of the base of the points (Fig. 9): a beveled end for the simple-beveled points, a V-shaped housing for the base of the double-beveled points, and a socket for the massive bases. The base of the points was fixed with hide glue, lashed with sinew, and the lashing was then protected with a second layer of hide glue.

\subsection{Experimental setting and implementation}

The experiment took place during the winter in cold and dry weather. The targets were the bodies of two young female deer, weighing about $50 \mathrm{~kg}$, purchased from a cattle farm and slaughtered under veterinary control immediately before the beginning of the experiment. The carcasses were complete and had not been subject to any treatment such as freezing, skinning, evisceration, partial defleshing, etc. They were loosely suspended in a lifelike position to a wooden bracket, with one side facing the experimenters. The bracket was set up before a rocky slope in a wooded environment (Fig. 10). The ground, hardened by frost, was covered with a white plastic sheet for easier recovering of the tip fragments (Barton and Bergman, 1982).

One animal was shot with the spears bearing the Lower Magdalenian replicas, and the other one with the spears bearing the replicas of Pincevent-IV20. The spearthrower users (P. Cattelain, P. Chauvaux, T. Chauvaux, E. Demoulin) were all experimented practitioners, with the instruction to aim at the vital organs of the animals (heart/lungs zone). The shooting distance was set at $12 \mathrm{~m}$; this distance was considered consistent with ethnographic information on spearthrower hunting, where "in any case, the hunter attempts to approach game as closely as possible" before shooting (Cattelain, 1997: p. 230; see also Hutchings and Brüchert, 1997).

Unlike several previous studies (Carrère, 1990; Geneste and Plisson, 1993; Stodiek, 1993, 2000), we favored "real" spearthrower shooting over the use of a calibrated crossbow. A detailed discussion of this choice is beyond the scope of this article, and it will only be shortly explained here. A calibrated crossbow would have allowed to standardize spear velocities and to precisely select the point of aim. However, even if it can be set to simulate the average initial launching speed of a spearthrower-propelled projectile, a crossbow will not duplicate its specific ballistic behavior. Briefly speaking, a crossbow is essentially a spring, storing and releasing energy, while the spearthrower acts as a lever, transmitting and amplifying the user's strength. This results in different flight aerodynamics, with spearthrower projectiles having a much more pronounced spine, likely to affect the tip's reaction upon impact (Pétillon, 2005, 2006). Moreover, the speed measurements made by Stodiek suggest that individual variations in spearthrower use are quite limited when standardized equipment is put in trained hands (Stodiek, 1993: Fig. 176).

The 34 spears were shot 74 times, and 44 shots hit the target. Impacts are centered on the thorax (ribs and sternum), abdomen, thigh muscle and thoracic vertebrae. Only five shots hit respectively the innominate, scapula, humerus, one cervical and one lumbar vertebra. Each impact was photographed and recorded on an individual form. Each spear was shot repeatedly until the osseous point, the shaft or the hafting was damaged. The backed bladelets detached 
after impact were immediately glued back if intact or replaced if broken or lost. The lithic elements detached from the points were systematically sought after, on the ground surrounding the animals, then inside the carcasses during their processing. The carcasses were processed immediately after the shooting session, and the bones were defleshed, cleaned and kept for the study of impact traces.

\section{Results}

\subsection{The antler points}

\subsubsection{Penetration}

In 30 of the 44 hits, the antler point successfully penetrated the animal's hide and flesh. In 14 cases, at least one impact trace could be recorded on the bones of the target (crushing, notch, puncture, perforation, or cut made by a bladelet: see terminology in Castel, 2008; Letourneux and Pétillon, 2008; Morel, 2000). As documented in earlier experiments (Letourneux and Pétillon, 2008; Morel, 2000; Pokines, 1998; Stodiek, 1993, 2000), the points proved resistant enough to pierce through bones such as vertebrae (Fig. 11) or a scapula with a rib behind it (Fig. 12). The 13 successful hits made by bare points and "stripped" points (i.e., points whose bladelets all came off without penetration: see 4.2.1.) into the thorax, thigh muscle, sternum and thoracic vertebrae achieved a mean penetration depth of $148 \mathrm{~mm}$ (Table 4). This result is in accordance with previous experiments with bare points made of antler (Pétillon, 2006; Pokines, 1998; Stodiek, 1993, 2000). The deeper penetrations achieved in the thoracic area by Guthrie's (1983) experiment with bone and antler points are most likely a function of the much greater propulsive force applied to his projectiles (500 g fiberglass shafts fired from a compound bow at a range of $5 \mathrm{~m}$ : Pokines, 1998).

The 14 unsuccessful hits include two different situations. The first one corresponds to 4 impacts in which the penetration of the point was halted by a larger, thicker bone (humerus, innominate, body of one cervical and one lumbar vertebra). The second situation corresponds to 10 impacts in which the projectile literally bounced off the target after shallow penetration $(<10 \mathrm{~cm})$. This problem is mostly due to a mistake in the hafting design of one sub-type of points (the smaller points with massive base): the sockets in which those points were hafted were wider than the base of the point, and formed a shouldered protrusion that prevented efficient penetration (Fig. 9). The importance of this "hilt effect" (Guthrie, 1983) is shown in the fact that 6 of the 8 hits with this type of point bounced off $(75 \%)$, while among the 32 hits with other types of points - the 4 impacts on large bones being excluded - only 4 bounces occurred (12.5\%).

\subsubsection{Durability}

Most shots in the target caused no macroscopic damage to the antler points. Only the impacts on the humerus and the scapula broke the tip of two points, causing them to loose 14 and 3 $\mathrm{mm}$ of their original length. One impact in the thorax and one in a thoracic vertebra resulted in a slight crushing of the tip on two other points. In all four instances, the damaged tip would have been easily repaired by resharpening. The very high impact resistance of antler points was stressed by almost all experimenters (Arndt and Newcomer, 1986; Bergman, 1987; Knecht, 1993, 1997b; Pétillon, 2005, 2006; Pokines, 1998). Here again, as noted by Arndt and Newcomer (1986), Knecht (1997b) and Pokines (1998), the low durability of antler points in the experiment by Guthrie (1983) is at odds with all subsequent results and is probably due to the specific experimental protocol employed. 
The picture changes, however, when considering the 30 shots that missed the target and impacted the ground, rocks and vegetation behind the animal. The state of the point after impact could be documented in 29 cases (the last point was ejected from its haft upon impact and lost). In 21 cases (72.4\%), damage occurred in the form of tip crushing $(n=5)$, tip fracture $(n=15)$ or even breakage of the point at the joint with the shaft $(n=1)$. The length lost by the 16 broken points varies from 1 to $76 \mathrm{~mm}$ (mean: 13.8), and at least 3 of them were considered irreparable. The destructing effects of misses impacting hard obstacles was not documented by previous experimenters with osseous points, because they had set up a less damaging background to their targets (hay bales, grassy field, etc.) or used a crossbow to avoid misses entirely. In this respect, the choice of our shooting stand (a rocky slope) was deliberate, as we believe that these experimental conditions are a closer approximation of a "realistic" hunting situation in a Palaeolithic environment.

During the shooting session, the joint between the point and the shaft appeared as a critical point: damage to this area was one of the main causes of spears being withdrawn from the experiment. Breakage of the shaft in the hafting area occurred with 3 of the 44 hits $(6.8 \%)$ and 9 of the 30 misses (30\%). The point coming out of its shaft (without damage to the shaft) or the loosening of the haft occurred in 6 of the 44 hits $(13.6 \%)$ and 5 of the 30 misses $(16.6 \%)$.

\subsection{The retouched microliths}

\subsubsection{Penetration}

The performance of the lithic inserts was quite varied. Twenty-two of the 30 successful hits involved points with one or several laterally-hafted flint bladelets. In 5 cases, the bladelets entirely failed to cut through the animal's hide and were ripped off the point when it entered the target's body (these impact are termed "stripped points" in Table 4). These bladelets either were found clustered on the target's hide, next to the hole made by the point, or were expelled by the force of impact up to several meters from the target. As will be discussed below, this problem is most probably due to a number of design flaws in our experimental projectiles (see 5.).

Of the remaining 17 hits with bladelets, 2 could not be documented (the bladelets came off and could not be found, preventing us to determine if they had made their way into the carcass). With the other 15 hits, even if part of the lithic row(s) sometimes came off upon impact, at least one lithic element managed to slice through the hide and penetrate the target's body. These sharp spear tips penetrated deeper into the carcass than the bare and the stripped antler points (Table 4): the mean penetration depth for these hits is $283 \mathrm{~mm}$, that is, 1.91 times the mean penetration depth achieved in the same areas by points without bladelets (see 4.1.1). The majority of these 15 impacts with bladelets $(n=9)$ even resulted in the projectile going through the carcass. Penetration depths beyond $250 \mathrm{~mm}$ in the thoracic region of fallow deer and goat bodies had been recorded by Stodiek (1993) and Cattelain and Perpère (1993) for spears equipped with flint points; stone-tipped arrows fired at ballistics gel reached penetrations ca. 210-250 $\mathrm{mm}$ in the experiments by Waguespack et al., 2009 (see also Sisk and Shea, 2009).

We examined correlations between penetration depth and a number of other parameters (point type, spear mass, identity of the thrower) and found no significant relationship. Thus the increase in average penetration depth is clearly due to the presence of the flint bladelets; it is not linked to differences in the robustness of distinct base types, in the weight of the projectiles or in the respective strength of the throwers.

Furthermore, a plot of penetration depth against the number of microliths that passed through the hide hints at a possible relation between these two parameters (Fig. 13). Except for two 
impacts with a very deep penetration $(330$ and $470 \mathrm{~mm})$ and a low number of microliths (1 and 2), it seems that the hits with the deepest penetration are the ones where the highest number of microliths made their way into the body. Although this parameter clearly deserves further testing with a larger sample, it might be possible that increasing the number of microliths on the points enhances the potential effectiveness of the weapon. However, our sample size is too small to test if arranging a given number of microliths in one row or in two symmetrical rows influenced penetration.

\subsubsection{Durability}

As mentioned above, the durability of the added cutting edges was poor because of a low cohesion with the point. Of the 82 microliths hafted on points that hit the target, 67 came off (33 outside the carcass, 25 inside it, the position of 9 remaining undetermined) - leaving only 15 specimens $(18.3 \%)$ still attached to the point after a hit. Misses were even more destructive: except a single occurrence, they always resulted in the shattering of the lithic rows, with all bladelets coming loose.

The first consequence of this low durability was a high rate of loss: despite close examination of the shooting ground after each shot and careful processing of the carcasses, 41 of the 101 microliths were lost $(40.6 \%)$.

The second consequence is the small development of the macroscopic impact traces. These traces are present on $20 \%$ of the 60 bladelets observable after the experiment ( 5 of the 31 Lower Magdalenian specimens and 7 of the 29 Pincevent-IV20 specimens: Table 5; Fig. 14). This frequency is in accordance with the $10-30 \%$ trend generally observed in other projectile experiments with lithic tips (e.g., Christensen and Valentin, 2004). However, most of the traces on our sample are of very small extent, usually millimeter-scale, and he majority of them are not considered diagnostic of projectile use (notches on the cutting edge, less than 1 $\mathrm{mm}$ deep, are the damage most commonly observed; on lithic implements of this morphology, this type of break can occur during manufacture, transport or trampling, and is not diagnostic unless associated with other, more explicit traces).

This situation departs from several traceological results on UP bladelets, especially from the Magdalenian, where part of the sample usually show much more visible and unequivocal traces (e.g., Plisson and Vaughan, 2002). The most likely reason is that the low cohesion of our adhesive reduced the mechanical stress on the bladelets: when struck, the microliths would come off the point instead of breaking. The tendency of laterally-hafted backed bladelets to break loose from their shaft without breaking was also noted in the experiments by Crombé et al. (2001: p. 260), Moss and Newcomer (1982: p. 296) and O'Farrell (1996: p. 72).

\section{Experimental summary and prospects}

This pilot experiment raised a number of problems that should be given particular attention in the future when implementing projectile experiments with composite tips.

- Perfect streamlining is a must: the hafting of certain types of points must be reconsidered so as to avoid any hilt effect.

- Selecting a stronger type of wood for the shafts might reduce the number of breaks in the hafting area. The duramen of pine wood would probably be a good solution. This choice will also provide a heavier wood than the one used.

- A slight increase of the diameter of the hafts (at least up to $16 \mathrm{~mm}$ ) would correspond better with certain ethnographic examples (Cattelain, 1994: p. 9-10), and would increase the weight - hence the kinetic energy - of the spears. This would allow to test how much this variable is 
related to penetration and to damage made to both the bones and the points. Using these heavier projectiles will entail a new training for the shooters.

- Special care must be given to the design of the head bladelet: failure of this bladelet to enter the hide usually proves fatal to the whole lithic row behind it. This bladelet should always present a curved cutting edge and a pointed distal end in order to optimize penetration of the flint elements. This constraint is so strong that, in our opinion, this criterion might be used to identify potential head bladelets in archaeological assemblages. Symmetrically, tip designs that do not take this constraint into account can be ruled out from the range of potential technical choices a hunter might appropriately choose from.

- The low cohesion of the flint bladelets with the points appears as recurrent feature of our experimental projectiles (and of several previous studies as well). The amount of adhesive used might be one of the reasons behind this result: further experiments should consider a larger spreading of the mastic, completely wrapping the sides of the microliths and leaving only the cutting edge exposed. The nature of the mastic might also be questioned: further analysis of the residue observed on several Magdalenian lithic elements, notably at Montespan (Plisson, 2007) and Lascaux (Allain, 1979), should be considered. The use of a modern adhesive could also be a complementary experimental perspective, in order to rule out this parameter and establish more comprehensive baseline data on the efficiency of flint (micro)bladelets.

\section{Discussion}

Despite these limitations and although the experimental sample is quite small, this experiment provided one of the first practical, controlled and quantified assessment of the performance of UP composite tips. The classic view of these projectile tips as a combination of toughness and cutting power found one of its first experimental confirmations. The antler points are able to effectively pierce the hide of the target and break through some of the bones, usually without taking significant damage. Adding a flint edge to these points allows to nearly double the mean penetration depth (in the same body areas, and all other conditions being equal), equaling the penetration capacity of spears equipped with flint points alone. In several cases, composite tips were able to completely cut through the target's body. Additionally, the number of microliths (i.e., the length of the cutting edge) might play a role in augmenting the penetration of the projectile.

In this study, penetration capability (including penetration depth and damage to the bones) was used as a measure of the weapon's efficiency in killing prey: it is assumed that a deeper wound will cause more internal damage to the target, by increasing the chance that vital viscera or large blood vessels get severed. However, we are aware that penetration is not the only performance standard for projectile points. When discussing the ability of a hunting weapon to bring down game, other variables, more difficult to address experimentally, include stopping power (the "shock" power of the projectile: Carrère, 1990) and hemorrhage size (the ability to produce wide, bleeding wounds). Stopping power was not the concern of our study because it is more influenced by the speed, mass and dimensions of the spear than by the characteristics of its tip (except in the specific case of blunt "stun" tips, not relevant here). Hemorrhage, conversely, chiefly depends on tip features. It is possible that the intention of the hunter, when adding lithic inserts to an antler point, was above all to increase blood loss. Nevertheless, here, in the case of piercing projectiles (as opposed to slashing/tearing projectiles, e.g. transverse arrowheads), bleeding occurs through in-depth cutting - meaning that, in this study, penetration is still a good proxy of general lethality.

The issue of hemorrhage raises another interpretation problem for our results. The loosening of flint elements inside the prey is likely to cause additional bleeding and aggravate the 
wound. As such, it was sometimes suggested to be an intended effect: the brittleness of stone tips would not have been only a liability but also a supplementary argument in favor of their lethality (Elston and Brantingham, 2002: p. 104; Lombard and Pargeter, 2008: p. 2526; Lombard and Phillipson, 2010: p. 636). If we follow this hypothesis, the low cohesion of the flint insets with the antler points in our experiment should not be considered as a design flaw of our protocol, but could actually reflect the choice of the Magdalenian hunters. However, the arguments for this are not decisive. Breakage of stone points on impact with the target bodies was recorded experimentally (e.g., Lombard and Phillipson, 2010: Fig. 1), but the added effect of this splintering on the prey - as opposed to a "clean" wound - was never systematically described and is very difficult to observe under controlled experimental conditions. Furthermore, as Ellis points out (Ellis, 1997: p. 52), his extensive literature search on the use of stone points yielded only two ethnographic observations supporting this idea. And most importantly, the most frequent problem encountered in our experiment was not the dislodging of flint elements inside the prey but the failure of the bladelets to enter the body which can hardly be considered as a deliberately designed feature of the Magdalenian composite tips. At this stage of our experiments, a firmer hafting of the bladelets on the points seems far more likely to be desirable.

The widespread use of composite tips for land game hunting is documented in several phases of the western European Upper Palaeolithic and in the Mesolithic of continental Europe. Many variants exist (variations in base shape, microlith design, etc.) and their environmental contexts of use are equally varied - notably, they do not appear linked to one particular game type. The specificity of these tips might actually lie in their adaptability: a rather lightweight projectile head that combines the resilience of antler and the sharpness of flint edges will be efficient against both large herbivores with thick hide and smaller, perhaps more elusive ungulate species.

However, this experiment also allowed to pinpoint the technical constraints surrounding the design and operation of composite tips. As might have been expected from a compound object, the critical points for the efficiency and durability of the system are the interfaces between the different components: the joint between the bladelets and the points, and the joint between the point and the shaft. Compared to "simple" points, either organic or mineral, composite tips involve an increase in design complexity and in the time and effort expended on manufacture and repair, with maintenance activities unlikely to have been carried out in the hunting field. Thus, weapons of this kind may be termed very reliable but not very maintainable in Bleed's (1986) sense. They imply a certain degree of planning and anticipation, in order to make sure that a sufficient supply of all components is available, and to ensure the necessary "retooling" and "gearing up" operations. These implications agree with the evidence of planned hunting activities known for the Upper Magdalenian in the Paris Basin (especially the killing of reindeer in large numbers during their fall migration: e.g., Enloe, 2000). In a broader perspective, the Magdalenian, at least in its middle and upper phases, seems to be marked by an increased anticipation in several economic domains, including the acquisition of lithic and antler raw materials (e.g., Langlais, 2010; Averbouh, 2000). The variability of archaeological hunter-gatherer cultures displaying composite tip use makes it difficult to assess if this correlation is valid beyond the Magdalenian case. Nevertheless, the results of this experimental study shed a new light on the actual performance of this type of weapon and provided new data to be integrated in the discussion on the evolution of Palaeolithic weaponry.

\section{Acknowledgements}

The authors would like to thank all their colleagues who participated in the different steps of 
this research, from the discussion of the experimental protocol through the manufacture of the material and the shooting session to the final data processing: Pascal Chauvaux, Thomas Chauvaux, Lucie Chehmana, Marianne Christensen, Emmanuel Demoulin, Colas Guéret, Claire Letourneux, Isabelle de Miranda and Jacques Pelegrin. We are grateful to seven anonymous reviewers who provided very useful comments on the manuscript, and to Thomas Perrin for his advice and assistance. Funding was provided by the Collective Research Project "Habitats et peuplements tardiglaciaires du Bassin parisien" and logistical support by the Cedarc/Musée du Malgré-Tout, laboratories ArScAn (UMR 7041) and TRACES (UMR 5608).

\section{References}

Allain, J., 1979. L'industrie lithique et osseuse de Lascaux. In: Leroi-Gourhan, Arl., Allain, J. (Eds.), Lascaux inconnu. CNRS (Suppléments à Gallia Préhistoire, 12), Paris, pp. 87-120.

Allain, J., Descouts, J., 1957. À propos d'une baguette à rainure armée de silex découverte dans le Magdalénien de Saint-Marcel. L'Anthropologie 61, 503-512.

Allain, J., Rigaud, A., 1986. Décor et fonction: quelques exemples tirés du Magdalénien. L'Anthropologie 90, 713-738.

Allain, J., Rigaud, A., 1989. Colles et mastics au Magdalénien. In: Olive, M., Taborin, Y. (Eds.), Nature et Fonction des Foyers Préhistoriques. APRAIF (Mémoires du musée de Préhistoire d'Ile-de-France, 2), pp. 221-223. Nemours.

Arndt, S., Newcomer, M.H., 1986. Breakage patterns on prehistoric bone points. In: Roe, D.A. (Ed.), Studies in the Upper Palaeolithic of Britain and Northwest Europe. Archaeopress (BAR International Series, 296), Oxford, pp. 165-173.

Audouin, F., Plisson, H., 1982. Les ocres et leurs témoins au Paléolithique en France: enquête et expériences sur leur validité archéologique. Cahiers du Centre de Recherches Préhistoriques 8, 33-80.

Aveling, E.M., Heron, C., 1999. Chewing tar in the early Holocene: an archaeological and ethnographic evaluation. Antiquity 73, 579-584.

Averbouh, A., 2000. Technologie de la Matière Osseuse Travaillée et Implications Palethnologiques. PhD dissertation, université Paris I.

Averbouh, A., Julien, M., 2004. L'Armement magdalénien en matières osseuses dans le Bassin parisien. In: Valentin, B., Bodu, P., Julien, M. (Eds.), Habitats et Peuplements Tardiglaciaires du Bassin Parisien, Projet Collectif de Recherche 2003-2005, Rapport d'Activité pour 2004. UMR 7041, Nanterre, pp. 75-78. http://hdl.handle.net/2332/1205.

Bárta, J., 1989. Hunting of brown bears in the Mesolithic: evidence from the Medvedia cave near Ru_zín in Slovakia. In: Bonsall, C. (Ed.), The Mesolithic in Europe. John Donald Publishers, Edinburgh, pp. 456-460.

Barton, R.N.E., Bergman, C.A., 1982. Hunters at Hengistbury: some evidence from experimental archaeology. World Archaeology 14, 237-248.

Bazile, F., Guillerault, P., Monnet, C., 1989. L'habitat paléolithique supérieur de plein air de Fontgrasse, travaux 1983-87. Gallia Préhistoire 31, 65-92.

Bergman, C.A., 1987. Hafting and use of bone and antler points from Ksar Akil, Lebanon. In: Stordeur, D. (Ed.), La main et l'outil: manches et emmanchements préhistoriques. CNRS (Travaux de la Maison de l'Orient, 15), Paris, pp. 117-126.

Bergman, C.A., 1993. The development of the bow in Western Europe: a technological and functional perspective. In: Peterkin, G.L., Bricker, H.M., Mellars, P. (Eds.), Hunting and Animal Exploitation in the Later Palaeolithic and Mesolithic of Eurasia. American Anthropological Association (Archeological Papers of the American Anthropological Association, 4), Washington, D.C, pp. 95-105. 
Bleed, P., 1986. The optimal design of hunting weapons: maintainability or reliability. American Antiquity 51, 737-747.

Bodu, P., 1993. Analyse Typo-technologique du Matériel Lithique de quelques Unités du Site Magdalénien de Pincevent (Seine-et-Marne). Applications Spatiales, Économiques et Sociales. PhD dissertation, université de Paris 1.

Bon, F., 2002. L'Aurignacien entre Mer et Océan. Réflexion sur l'Unité des Phases Anciennes de l'Aurignacien dans le Sud de la France. Société préhistorique française (Mémoires, 29), Paris.

Bon, F., 2005. Little big tool. Enquête autour du succès de la lamelle. In: Le Brun-Ricalens, F., Bordes, J.-G., Bon, F. (Eds.), Productions Lamellaires Attribuées à l'Aurignacien: Chaînes Opératoires et Perspectives Technoculturelles. MNHA (ArchéoLogiques, 1), Luxembourg, pp. 479-484.

Bordes, J.-G., 2002. Les Interstratifications Châtelperronien/Aurignacien du Roc-de-Combe et du Piage (Lot, France). Analyse Taphonomique des Industries Lithiques; Implications Archéologiques. PhD dissertation, université de Bordeaux 1. http://grenet.drimm.ubordeaux1.fr/pdf/2002/BORDES_JEAN-GUILLAUME_2002.pdf.

Borgia, V., 2008. Ancient Gravettian in the south of Italy: functional analysis of backed points from grotta Paglicci (Fogia) and grotta della Cala (Salerno). Palethnologie 1, 45-65. http://www.palethnologie.org/revue.php?numero1/41\&partie1/41.

Bosinski, G., 2010. The hafting of backed bladelets in the Late Magdalenian. In: Burdukiewicz, J.M., Cyrek, K., Dyczek, P., Szymczak, K. (Eds.),Understanding the Past: Papers Offered to Stefan K. Kos1owski. University of Warsaw, Warsaw, pp. 55-58.

Carrère, P.,1990. Contribution de la balistique au perfectionnement des études technofonctionnelles des pointes de projectiles préhistoriques. Paléo 2, 167-176.

Castel, J.-C., 2008. Identification des impacts de projectiles sur le squelette des grands ongulés. Annales de Paléontologie 94, 103-118.

Cattelain, P., 1994. La chasse au Paléolithique supérieur: arc ou propulseur, ou les deux? Archéo-Situla 21-24, 5-26.

Cattelain, P., 1997. Hunting during the upper Paleolithic: bow, spearthrower, or both? In: Knecht, H. (Ed.), Projectile Technology. Plenum Press (Interdisciplinary contributions to archaeology), New York, pp. 213-240.

Cattelain, P., 2004. Un propulseur inédit de la Grotte du Placard (Vilhonneur, Charente, France). Notae Praehistoricae 24, 61-67.

Cattelain, P., 2005. Propulseurs magdaléniens: marqueurs culturels régionaux? In: Dujardin, V. (Ed.), Industrie osseuse et parures du Solutréen au Magdalénien en Europe. Société préhistorique française (Mémoires, 34), Paris, pp. 301-317.

Cattelain, P., Perpère, M., 1993. Tir expérimental de sagaies et de flèches emmanchées de pointes de la Gravette. Archéo-Situla 17-20, 5-28.

Cattelain, P., Perpère, M., 1996. Tir expérimental de répliques de pointes de la Gravette: bilan et perspectives. Notae Praehistoricae 16, 55-61.

Cazals, N., 2000. Constantes et Variations des Traits Techniques et Économiques entre le Magdalénien "Inférieur" et "Moyen": Analyse des Productions Lithiques du Nord de la Péninsule Ibérique. PhD dissertation, université de Paris 1.

Christensen, M., Valentin, B., 2004. Armatures de projectiles et outils: de la production à l'abandon. In: Pigeot, N. (Ed.), Les Derniers Magdaléniens d'Étiolles: Perspectives Culturelles et Paléohistoriques (l'Unité d'Habitation Q31). CNRS (Suppléments à Gallia Préhistoire, 37), Paris, pp. 107-160.

Crombé, P., Perdaen, Y., Sergant, J., Caspar, J.-P., 2001. Wear analysis on early Mesolithic microliths from the Verrebroek site, East Flanders, Belgium. Journal of Field Archaeology 28, 253-269. 
David, F., 1972. Annexe III: témoins osseux. In: Leroi-Gourhan, A., Brézillon, M. (Eds.), Fouilles de Pincevent. Essai d'Analyse Ethnographique d'un Habitat Magdalénien. CNRS (Suppléments à Gallia Préhistoire, 7), Paris, pp. 295-320.

David, F.,1994. La faune de Pincevent et Verberie. In: Taborin,Y. (Ed.), Environnements et Habitats Magdaléniens dans le Centre du Bassin Parisien. Maison des sciences de l'homme (Documents d'archéologie française, 43), Paris, pp. 105-110.

David, F., Orliac, M., 1994. Pincevent. In: Taborin, Y. (Ed.), Environnements et Habitats Magdaléniens dans le Centre du Bassin Parisien. Maison des sciences de l'homme (Documents d'archéologie française, 43), Paris, pp. 154-166.

Debout, G., 2003. Les microlithes du Magdalénien supérieur dans le Bassin parisien: une diversité inattendue. In: Ladier, É (Ed.), Les Pointes à Cran dans les Industries du Paléolithique Supérieur Récent de l'Oscillation de Lascaux à l'Oscillation de Bølling. Préhistoire du Sud-Ouest (Supplément, 6), pp. 91-99.

Delporte, H., Hahn, J., Mons, L., Pinçon, G., de Sonneville-Bordes, D., 1988. Fiches Typologiques de 1'Industrie Osseuse Préhistorique: Cahier I, Sagaies. Publications de l'université de Provence, Aix-en-Provence.

Dinnis, R., Pawlik, A., Gaillard, C., 2009. Bladelet cores as weapon tips? Hafting residue identification and micro-wear analysis of three carinated burins from the late Aurignacian of LesVachons, France. Journal of Archaeological Science 36, 1922-1934.

Dolukhanov, P., 2008. The Mesolithic of European Russia, Belarus and the Ukraine. In: Bailey, G., Spikins, P. (Eds.), Mesolithic Europe. Cambridge University Press, Cambridge, pp. 280-301.

Ducasse, S., Langlais, M., 2007. Entre Badegoulien et Magdalénien inférieur, nos coeurs balancent. Approche critique des industries lithiques du sud de la France et du Nord-Est espagnol entre 19000 et 16500 BP. Bulletin de la Société Préhistorique Française 104, 771785.

Ellis, C.J., 1997. Factors influencing the use of stone projectile tips: an ethnographic perspective. In: Knecht, H. (Ed.), Projectile Technology. Plenum Press (Interdisciplinary contributions to archaeology), New York, pp. 37-74.

Elston, R.G., Brantingham, P.J., 2002. Microlithic technology in northern Asia: a riskminimizing strategy of the late Paleolithic and early Holocene. In: Elston, R.G., Kuhn, S.L. (Eds.), Thinking Small: Global Perspectives on Microlithization. American Anthropological Association (Archeological Papers of the American Anthropological Association, 12), Arlington, pp. 103-116.

Elston, R.G., Kuhn, S.L. (Eds.), 2002. Thinking Small: Global Perspectives on Microlithization. American Anthropological Association (Archeological Papers of the American Anthropological Association, 12), Arlington.

Enloe, J.G., 2000. Le Magdalénien du Bassin parisien au Tardiglaciaire: la chasse au renne comparée à celle d'autres espèces. In: Pion, G. (Ed.), Le Paléolithique supérieur récent: nouvelles données sur le peuplement et l'environnement. Société préhistorique française (Mémoire 28), Paris, pp. 39-45.

Enloe, J.G., David, F., 1997. Rangifer herd behavior: seasonality of hunting in the Magdalenian of the Paris Basin. In: Jackson, L.J., Thacker, P.T. (Eds.), Caribou and Reindeer Hunters of the Northern Hemisphere. Avebury (Worldwide archaeology series), Aldershot, pp. 52-68.

Geneste, J.-M., Plisson, H., 1993. Hunting technologies and Human behavior: lithic analysis of Solutrean shouldered points. In: Knecht, H., Pike-Tay, A., White, R. (Eds.), Before Lascaux: The Complex Record of the Early Upper Paleolithic. CRC Press, Boca Raton, pp. 117-135.

González, J.E., Ibáñez, J.J., 1993. Utilización del instrumental lítico y funcionalidad del 
asentamiento en el yacimiento de Berniollo (Alava, España). In: Anderseon, P.C., Beyries, S., Otte, M., Plisson, H. (Eds.), Traces et Fonction: Les Gestes Retrouvés. Université de Liège, Service de Préhistoire (ERAUL, 50), pp. 97-104.

González Morales, M.R., Straus, L.G., 2009. Extraordinary early Magdalenian finds from El Mirón Cave, Cantabria (Spain). Antiquity 83, 267-281.

Grünberg, J.M., 2002. Middle Palaeolithic birch-bark pitch. Antiquity 76, 15-16.

Guthrie, R.D., 1983. Osseous projectile points: biological considerations affecting raw material selection and design among Paleolithic and Paleoindian people. In: Clutton-Brock, J., Grigson, C. (Eds.), Animals and Archaeology I: Hunters and Their Prey. Archaeopress (BAR International Series, 165), Oxford, pp. 273-294.

Houmard, C., 2003. Réflexions sur les têtes de projectiles rainurées d'après l'étude du site de La Garenne (Indre). Préhistoire Anthropologie Méditerranéennes 12, 165-172.

Houmard, C., Jacquot, É, 2009. Des têtes de projectile composites à "La Garenne". In: Despriée, J., Tymula, S., Rigaud, A. (Eds.), Données Récentes sur le Magdalénien de "La Garenne" (Saint-Marcel, Indre) et la Place du Magdalénien "à Navettes" en Europe. Archéologie du val de Creuse en Berry, Bulletin de l'ASSAAM special issue, Argentonsur-Creuse, pp. 137-150.

Hughes, S.S., 1998. Getting to the point: evolutionary change in prehistoric weaponry. Journal of Archaeological Method and Theory 5, 345-408.

Hutchings, W.K., Brüchert, L.W., 1997. Spearthrower performance: ethnographic and experimental research. Antiquity 71, 890-897.

Ibáñez, J.J., González, J.E., Ruiz, R., Berganza, E., 1993. Huellas de uso en silex en el yacimiento de Santa Catalina. Consideraciones sobre la manufactura del utillaje óseo y la funcionalidad del asentamiento. In: Anderseon, P.C., Beyries, S., Otte, M., Plisson, H. (Eds.), Traces et Fonction: Les Gestes Retrouvés. Université de Liège, Service de Préhistoire (ERAUL, 50), pp. 225-234.

Keeley, L.H., 1988. Lithic economy, style and use: a comparison of three Late Magdalenian sites. Lithic Technology 17, 19-25.

Klaric, L., Aubry, T., Walter, B., 2002. Un nouveau type d'armature en contexte gravettien et son mode de production sur les burins du Raysse (la Picardie, commune de Preuilly-surClaise, Indre-et-Loire). Bulletin de la Société Préhistorique Française 99, 751-764.

Knecht, H., 1993. Early Upper Palaeolithic approaches to bone and antler projectile technology. In: Peterkin, G.L., Bricker, H.M., Mellars, P. (Eds.), Hunting and Animal Exploitation in the Later Palaeolithic and Mesolithic of Eurasia. American Anthropological Association (Archeological Papers of the American Anthropological Association, 4), Washington, D.C, pp. 33-47.

Knecht, H., 1997a. The history and development of projectile technology research. In: Knecht, H. (Ed.), Projectile Technology. Plenum Press (Interdisciplinary contributions to archaeology), New York, pp. 3-35.

Knecht, H., 1997b. Projectile points of bone, antler and stone: experimental explorations of manufacture and use. In: Knecht, H. (Ed.), Projectile Technology. Plenum Press (Interdisciplinary contributions to archaeology), New York, pp. 191-212.

Koller, J., Baumer, U., Mania, D., 2001. High-tech in the Middle Palaeolithic: Neandertalmanufactured pitch identified. European Journal of Archaeology 4, 385-397.

Langlais, M., 2010. Les Sociétés Magdaléniennes de l'Isthme Pyrénéen. CTHS (Documents préhistoriques, 26), Paris.

Langlais, M., Mangado, J., 2007. Le Magdalénien entre le Rhône et l'Èbre: des frontières naturelles et culturelles vécues par les préhistoriques et perçues par les préhistoriens? In: Cazals, N., González Urquijo, J., Terradas, X. (Eds.), Frontières Naturelles et Frontières Culturelles dans les Pyrénées Préhistoriques/Fronteras Naturales y Fronteras Culturales en 
los Pirineos Prehistóricos. PubliCan - Ediciones de la Universidad de Cantabria, Santander, pp. 143-163.

Langlais, M., Ladier, E., Chalard, P., Jarry, M., Lacrampe-Cuyaubere, F., 2007. Aux origines du Magdalénien quercinois: les industries de la séquence inférieure de l'abri Gandil (Bruniquel, Tarn-et-Garonne). Paleo 19, 341-366.

Langlais, M., Pétillon, J.-M., de Beaune, S.A., Cattelain, P., Chauvière, F.-X., Letourneux, C., Szmidt, C., Bellier, C., Beukens, R., David, F., 2010. Une occupation de la fin du dernier maximum glaciaire dans les Pyrénées: le Magdalénien inférieur de la grotte des Scilles (Lespugue, Haute-Garonne). Bulletin de la Société Préhistorique Française 107, 5-51.

Lansac, P., 2004. Un cadre chronologique pour l'utilisation du propulseur et de l'arc durant le Paléolithique supérieur européen. Bulletin des Chercheurs de la Wallonie 43, 29-36.

Larsson, L., 1983. Agerød V: An Atlantic Bog Site in Central Scania. Acta Archaeologica Lundensia (Series in-8, 12), Lund.

Le Brun-Ricalens, F., Brou, L., 2003. Burins carénés-nucléus à lamelles: identification d'une chaîne opératoire particulière à Thèmes (Yonne) et implications. Bulletin de la Société Préhistorique Française 100, 67-83.

Le Brun-Ricalens, F., Bordes, J.-G., Bon, F. (Eds.), 2005. Productions Lamellaires Attribuées à l'Aurignacien: Chaînes Opératoires et Perspectives Technoculturelles. MNHA (ArchéoLogiques, 1), Luxembourg.

Leroi-Gourhan, A., 1983. Une tête de sagaie à armatures de lamelles de silex de Pincevent. Bulletin de la Société Préhistorique Française 80, 154-156.

Leroi-Gourhan, A., Brézillon, M. (Eds.), 1972. Fouilles de Pincevent. Essai d'Analyse Ethnographique d'un Habitat Magdalénien. CNRS (Suppléments à Gallia Préhistoire, 7), Paris.

Leroy-Prost, C., 2008. L'industrie sur matières dures animales. In: Glory, A., Delluc, B., Delluc, G. (Eds.), Les recherches à Lascaux (1952e1963). CNRS (Suppléments à Gallia Préhistoire, 39), Paris, pp. 119-166.

Letourneux, C., Pétillon, J.-M., 2008. Hunting lesions caused by osseous projectile points: experimental results and archaeological implications. Journal of Archaeological Science $35,2849-2862$.

Lombard, M., 2005. Evidence of hunting and hafting during the Middle Stone Age at Sibidu Cave, KwaZulu-Natal, South Africa: a multianalytical approach. Journal of Human Evolution 48, 279-300.

Lombard, M., 2007. The gripping nature of ochre: the association of ochre with Howiesons Poort adhesives and Later Stone Age mastics from South Africa. Journal of Human Evolution 53, 406-419.

Lombard, M., Pargeter, J., 2008. Hunting with Howiesons Poort segments: pilot experimental study and the functional interpretation of archaeological tools. Journal of Archaeological Science 35, 2523-2531.

Lombard, M., Phillipson, L., 2010. Indications of bow and stone-tipped arrow use 64000 years ago in KwaZulu-Natal, South Africa. Antiquity 84, 635-648.

Márquez, B., Muñoz, J.F., 2008. Barbed and tanged arrowhead of extra-Cantabrian Solutrean: experimental progamme. In: Longo, L., Skakun, N. (Eds.), "Prehistoric Technology" 40 Years Later: Functional Studies and the Russian Legacy. Archaeopress (BAR International series 1783), Oxfzord, pp. 379-382.

Mazza, P., Martini, F., Sala, B., Magi, M., Colombini, M., Giachi, G., Landucci, F., Lemorini, C., 2006. A new Palaeolithic discovery: tar-hafted stone tools in a European MidPleistocene bone-bearing bed. Journal of Archaeological Science 33, 1310-1318.

Morel, P., 2000. Impacts de chasse et archéozoologie: quelques observations expérimentales. In: Bellier, C., Cattelain, P., Otte, M. (Eds.), La Chasse dans la Préhistoire/Hunting in 
Prehistory. SRBAP (Anthropologie et Préhistoire, 111) - Université de Liège, Service de Préhistoire (ERAUL, 51) - CEDARC (Artefacts, 8), Bruxelles, pp. 54-59.

Moss, E.H., 1983. The Functional Analysis of Flint Implements. Pincevent and Pont d'Ambon: Two Case Studies from the French Final Palaeolithic. Archaeopress (BAR International series 177), Oxford.

Moss, E.H., Newcomer, M.H., 1982. Reconstruction of tool use at Pincevent: microwear and experiments. In: Cahen, D. (Ed.), Tailler! Pour Quoi Faire: Préhistoire et Technologie Lithique, 2, Recent progress in microwear studies. Studia praehistorica belgica, 2, pp. 289312.

Nuzhnyj, D., 1989. L'utilisation des microlithes géométriques et non géométriques comme armatures de projectiles. Bulletin de la Société Préhistorique Française 86, 88-96.

Nuzhnyj, D., 1993. Projectile weapons and technical progress in the Stone Age. In: Anderseon, P.C.,, Beyries, S.,Otte, M., Plisson, H. (Eds.), Traces et Fonction: Les Gestes Retrouvés. Université de Liège, Service de Préhistoire (ERAUL, 50), pp. 41-54.

Nuzhnyj, D., 2000. Development of microlithic projectile weapons in the Stone Age. In: Bellier, C., Cattelain, P., Otte, M. (Eds.), La Chasse dans la Préhistoire/Hunting in Prehistory. SRBAP (Anthropologie et Préhistoire, 111) - Université de Liège, Service de Préhistoire (ERAUL, 51) - CEDARC (Artefacts, 8), Bruxelles, pp. 95-101.

Nuzhnyj, D., 2007.

[Development of the Microlithic Technique in the Stone Age: Improvement of the Weapons of the Primitive Hunters]. KNT Press (second edition), Kiev.

Owen, L.R., 1987. Hafting microblades. Examples from the Dorset culture of the North American arctic. In: Stordeur, D. (Ed.), La Main et l'Outil: Manches et Emmanchements Préhistoriques. CNRS (Travaux de la Maison de l'Orient, 15), Paris, pp. 147-150.

O'Farrell, M., 1996. Approche Technologique et Fonctionnelle des Pointes de la Gravette. MA dissertation, université de Bordeaux I.

O'Farrell, M., 2004. Les pointes de La Gravette de Corbiac (Dordogne) et considerations sur la chasse au Paléolithique supérieur ancien. In: Bodu, P., Constantin, C. (Eds.), Approches Fonctionnelles en Préhistoire. Société préhistorique française, Paris, pp. 121-138.

O'Farrell,M., 2005. Étude préliminaire des éléments d'armature lithique de l'Aurignacien ancien de Brassempouy. In: Le Brun-Ricalens, F., Bordes, J.-G., Bon, F. (Eds.), Productions Lamellaires Attribuées à l'Aurignacien: Chaînes Opératoires et Perspectives Technoculturelles. MNHA (ArchéoLogiques, 1), Luxembourg, pp. 395-412.

Pelegrin, J., O'Farrell, M., 2005. Les lamelles retouchées ou utilisées de Castanet. In: Le Brun-Ricalens, F., Bordes, J.-G., Bon, F. (Eds.), Productions Lamellaires Attribuées à l'Aurignacien: Chaînes Opératoires et Perspectives Technoculturelles. MNHA (ArchéoLogiques, 1), Luxembourg, pp. 103-121.

Pétillon, J.-M., 2005. Tir expérimental de pointes à base fourchue en bois de renne. In: Dujardin, V. (Ed.), Industrie osseuse et parures du Solutréen au Magdalénien en Europe. Société préhistorique française (Mémoires, 39), Paris, pp. 243-256.

Pétillon, J.-M., 2006. Des Magdaléniens en Armes: Technologie des Armatures de Projectile en Bois de Cervidé du Magdalénien Supérieur de la Grotte d'Isturitz (PyrénéesAtlantiques). CEDARC (Artefacts, 10), Treignes.

Pétillon, J.-M., 2008. Spécificités des armatures osseuses magdaléniennes du Bassin parisien. In: Valentin, B. (Ed.), Habitats et Peuplements Tardiglaciaires du Bassin Parisien, Projet Collectif de Recherche, Bilan des Activités de 2006 à 2008. UMR 7041/SRA d'Ile-deFrance, Nanterre/Saint-Denis, pp. 25-30. http://hdl.handle.net/2332/1479.

Pétillon, J.-M., 2009. Bilan d'une réalisation: tir expérimental d'armatures de sagaie composites: premiers résultats. Résumés des exposés au séminaire du 18/03/09. In: 
Valentin, B. (Ed.), Paléolithique Final et Mésolithique dans le Bassin Parisien et ses Marges, Habitats, Sociétés et Environnements, Projet Collectif de Recherche, Rapport d'Activités pour 2009. UMR 7041/SRA d'Ile-de-France, Nanterre/Saint-Denis, pp. 23-66. http://hdl.handle.net/2332/1610.

Plisson, H., 1985. Études Fonctionnelles des Outillages Préhistoriques par 1'Analyse des Micro-Usures: Recherche Méthodologique et Archéologique. PhD dissertation, université de Paris I.

Plisson, H., 2005. Examen tracéologique des pointes aziliennes du Bois-Ragot. In: Chollet, A., Dujardin, V. (Eds.), La Grotte du Bois-Ragot à Gouex (Vienne). Magdalénien et Azilien. Société préhistorique française (Mémoires, 38), Paris, pp. 183-189.

Plisson, H., 2007. La fonction des outils de silex dans les grottes ornées paléolithiques. In: Évin, J. (Ed.), Un Siècle de Construction du Discours Scientifique en Préhistoire, vol. 3. Société Préhistorique Française, Paris, pp. 125-132.

Plisson, H., Vaughan, P., 2002. Tracéologie. In: Cattin, M.-I. (Ed.), HauteriveChampréveyres. Un Campement Magdalénien au Bord du Lac de Neuchâtel: Exploitation du Silex (Secteur 1). Service et musée cantonal d'archéologie (Archéologie Nechâteloise, 26), Neuchâtel, pp. 90-105.

Pokines, J.T., 1998. Experimental replication and use of Cantabrian lower Magdalenian antler projectile points. Journal of Archaeological Science 25, 875-886.

Pokines, J.T., Krupa, M., 1997. Self-barbed antler spearpoints and evidence of fishing in the late Upper Paleolithic of Cantabrian Spain. In: Knecht, H. (Ed.), Projectile Technology. Plenum Press (Interdisciplinary contributions to archaeology), New York, pp. 241-262.

Primault, J., Brou, L., Gabilleau, J., Langlais, M., 2007. La grotte du Taillis des Coteaux à Antigny (Vienne): intérêts d'une séquence originale à la structuration des premiers temps du Magdalénien. Bulletin de la Société Préhistorique Française 104, 743-758.

Riede, F., 2009. The loss and re-introduction of bow-and-arrow technology: a case study from the Northern European Late Paleolithic. Lithic Technology 34, 27-45.

Riede, F., 2010. Hamburgian weapon delivery technology: a quantitative comparative approach. Before Farming [online version], 2010/1, article 1.

Rozoy, J.-G., 1992. Expérimentation de lancer de sagaies avec le propulseur. Bulletin de la société royale belge d'études géologiques et archéologiques, les chercheurs de la Wallonie 32, 169-184.

Sisk, M.L., Shea, J.J., 2009. Experimental use and quantitative performance analysis of triangular flakes (Levallois points) used as arrowheads. Journal of Archaeological Science 36, 2039-2047.

Soriano, S., 1998. Les microgravettes du Périgordien de Rabier à Lanquais (Dordogne). Analyse technologique fonctionnelle. Gallia Préhistoire 40, 75-94.

Stodiek, U., 1993. Zur Technologie der Jungpaläolithischen Speerschleuder: eine Studie auf der Basis Archäologischer, Ethnologischer und Experimenteller Erkenntnisse. Archaeologia Venatoria (Tübinger Monographien zur Urgeschichte, 9), Tübingen.

Stodiek, U., 2000. Preliminary results of an experimental investigation of Magdalenian antler points. In: Bellier, C., Cattelain, P., Otte, M. (Eds.), La Chasse dans la Préhistoire/Hunting in Prehistory. SRBAP (Anthropologie et Préhistoire, 111) - Université de Liège, Service de Préhistoire (ERAUL, 51) - CEDARC (Artefacts, 8), Bruxelles, pp. 70-78.

Straus, L.G., 1993. Upper Paleolithic hunting tactics and weapons in Western Europe. In: Peterkin, G.L., Bricker, H.M., Mellars, P. (Eds.), Hunting and Animal Exploitation in the Later Palaeolithic and Mesolithic of Eurasia. American Anthropological Association (Archeological Papers of the American Anthropological Association, 4), Washington, D.C, pp. 83-93.

Straus, L.G., 2000. A quarter-century of research on the Solutrean of Vasco-Cantabria, Iberia 
and beyond. Journal of Anthropological Research 56, 39-58.

Symens, N., 1986. A functional analysis of selected stone artifacts from the Magdalenian site at Verberie, France. Journal of Field Archaeology 13, 213-222.

Szmidt, C., Pétillon, J.-M., Cattelain, P., Normand, C., Schwab, C., 2009. Premières dates radiocarbone pour le Magdalénien d'Isturitz (Pyrénées-Atlantiques). Bulletin de la Société Préhistorique Française 106, 588-592.

Tiffagom, M., 2006. De la Pierre à l'Homme. Essai sur une Paléo-Anthropologie Solutréenne. Université de Liège, Service de Préhistoire (ERAUL, 113), Liège.

Valentin, B., 1995. Les Groupes Humains et leurs Traditions au Tardiglaciaire dans le Bassin Parisien: Apports de la Technologie Lithique Comparée. PhD dissertation, université de Paris I. http://tel.archives-ouvertes.fr/tel-00267435/fr/.

Valentin, B., 2008. Jalons pour une Paléohistoire des Derniers Chasseurs (XIVe-VIe millénaire avant J.-C.). Publications de la Sorbonne, Paris.

Valladas, H., 1994. Chronologie des sites du Magdalénien final du Bassin parisien. In: Taborin, Y. (Ed.), Environnements et Habitats Magdaléniens dans le Centre du Bassin Parisien. Maison des sciences de l'homme (Documents d'archéologie française, 43), Paris, pp. 65-68.

Wadley, L., 2005. Putting ochre to the test: replication studies of adhesives that may have been used for hafting tools in the Middle Stone Age. Journal of Human Evolution 49, 587601.

Wadley, L., 2006. Revisiting cultural modernity and the role of ochre in the Middle Stone Age. In: Soodyall, H. (Ed.), The Prehistory of Africa: Tracing the Lineage of Modern Man. Jonathan Ball Publishers, Johannesburg, pp. 49-63.

Waguespack, N.M., Surovell, T.A., Denoyer, A., Dallow, A., Savage, A., Hyneman, J., Tapster, D., 2009. Making a point: wood- versus stone-tipped projectile. Antiquity 83, 786800.

Zhilin, M.G., 1998. Technology of the manufacture of Mesolithic bone arrowheads on the Upper Volga. European Journal of Archaeology 1, 149-176. 

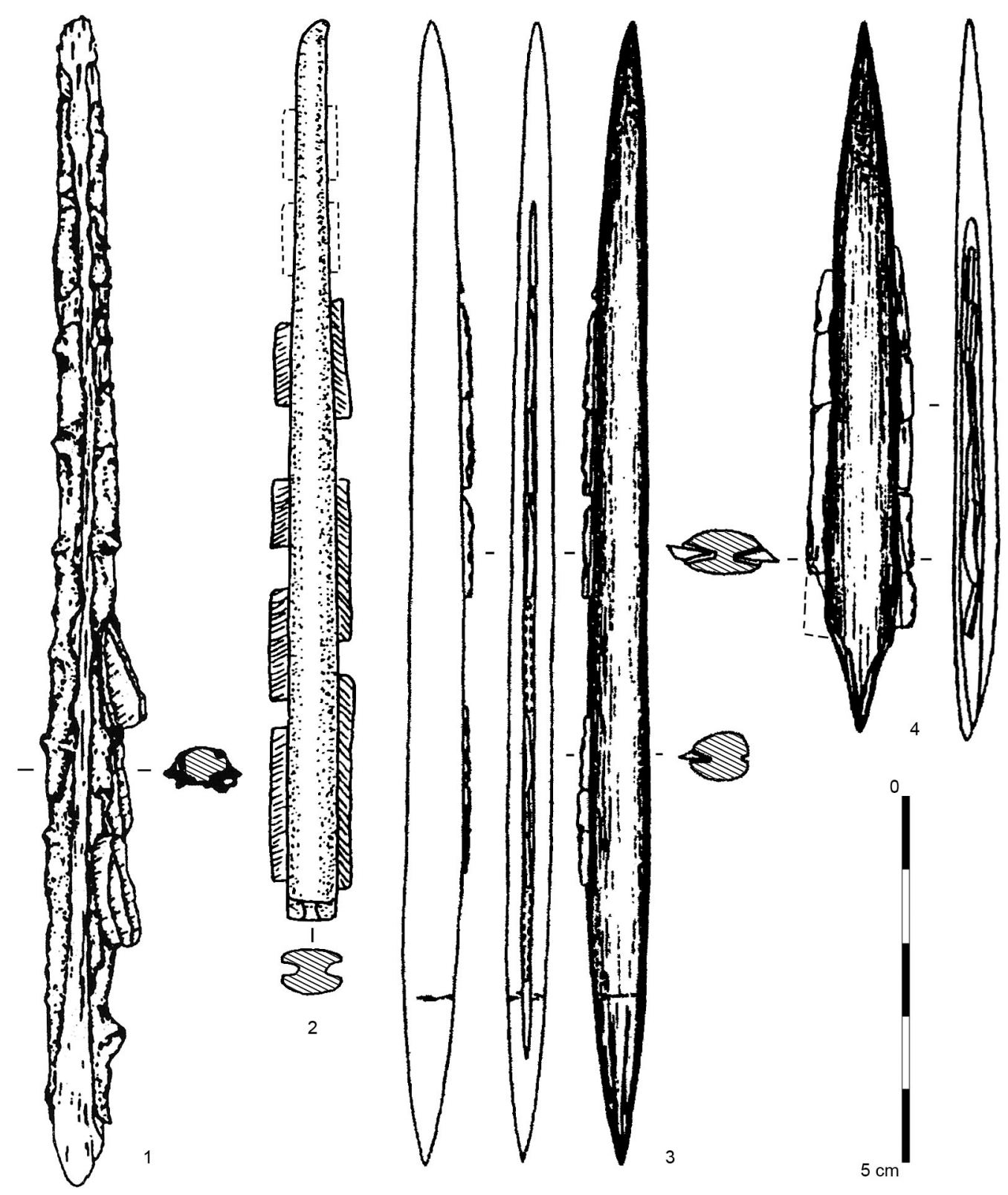

Fig. 1. Examples of Mesolithic osseous points found with flint elements still in place. 1: Agerød V, Scania, Sweden (after Larsson, 1983, in Bergman, 1993). 2: Medvedia cave, Ore mountains, Slovakia (after Bárta, 1989). 3: Stanovoye 4 (layer III), Upper Volga, Russia (after Zhilin, 1998). 4: Ivanovskoye 7 (layer IV), Upper Volga, Russia (after Zhilin, 1998). See also Dolukhanov, 2008. 

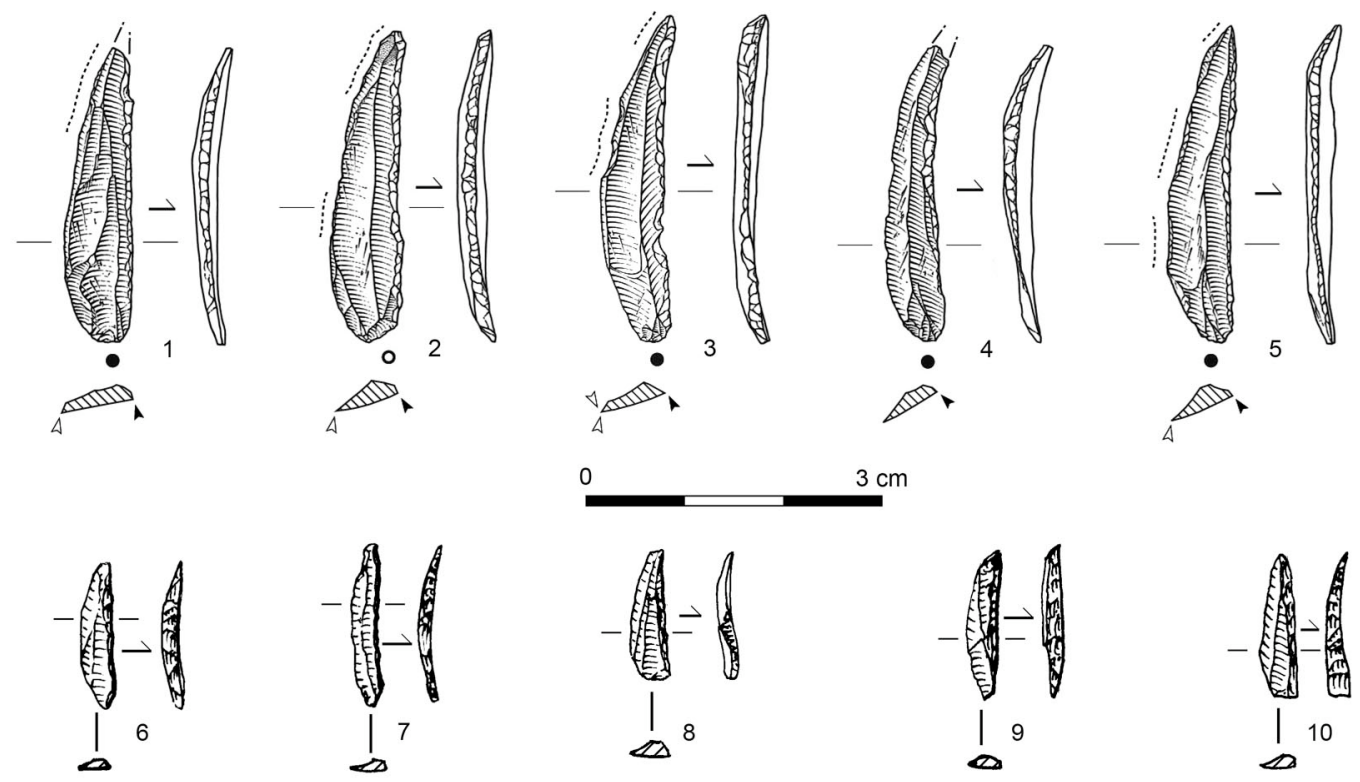

Fig. 2. Examples of backed bladelets (1-5: Petit Cloup Barrat, drawings S. Ducasse) and micro-bladelets (6-10: Gandil, drawings M. Jarry) from the Lower Magdalenian. 


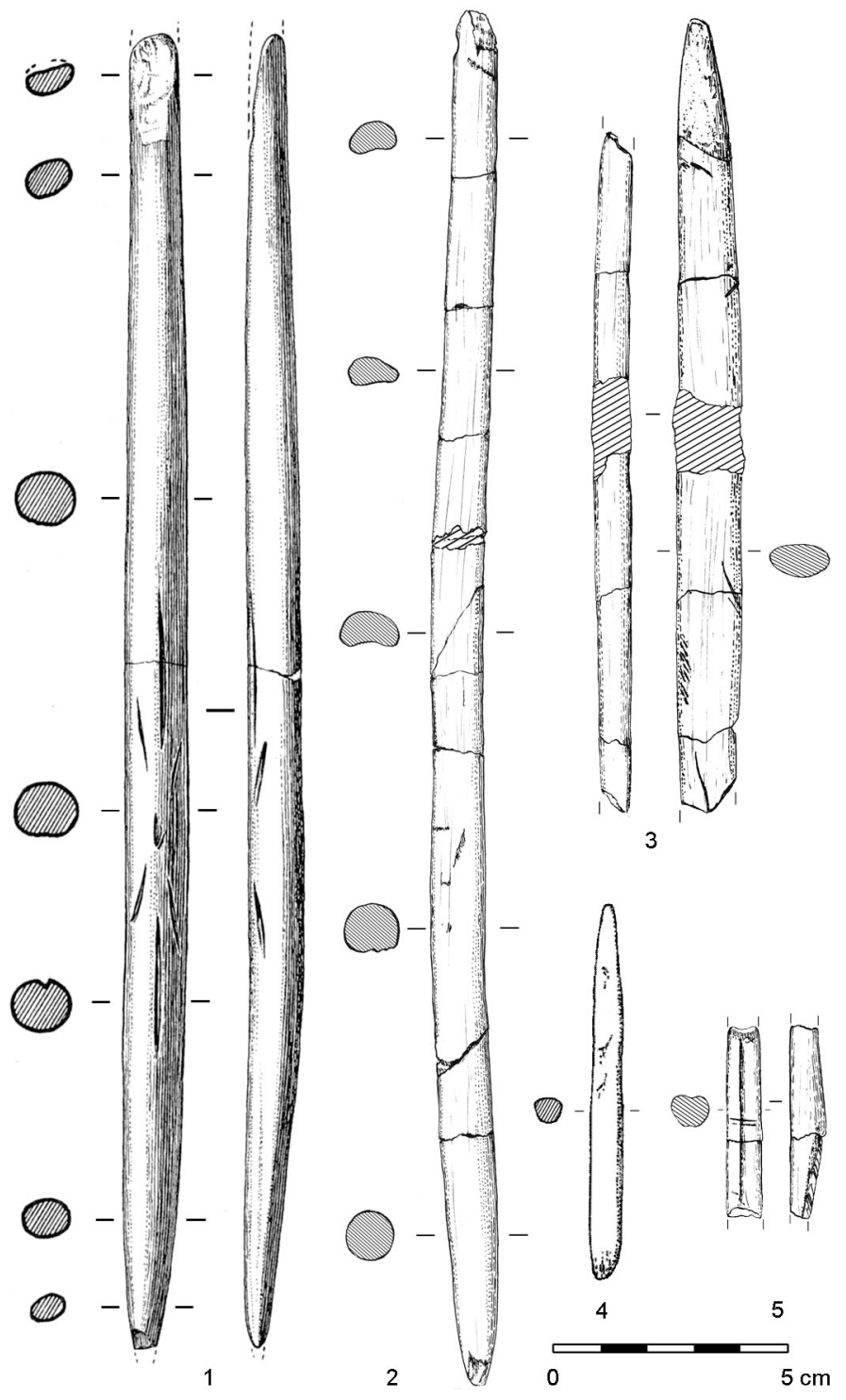

Fig. 3. Examples of antler points from the Lower Magdalenian. 1: large point with massive base, Lascaux (drawing J.-G. Marcillaud, after Leroy-Prost, 2008). 2, 3: large points with massive base, Scilles (drawings D. Molez, after Langlais et al., 2010). 4: small point with massive base, Gandil level 20 (after Ladier in Langlais et al., 2007). 5: simple-beveled point, Scilles (drawing D. Molez, after Langlais et al., 2010). 

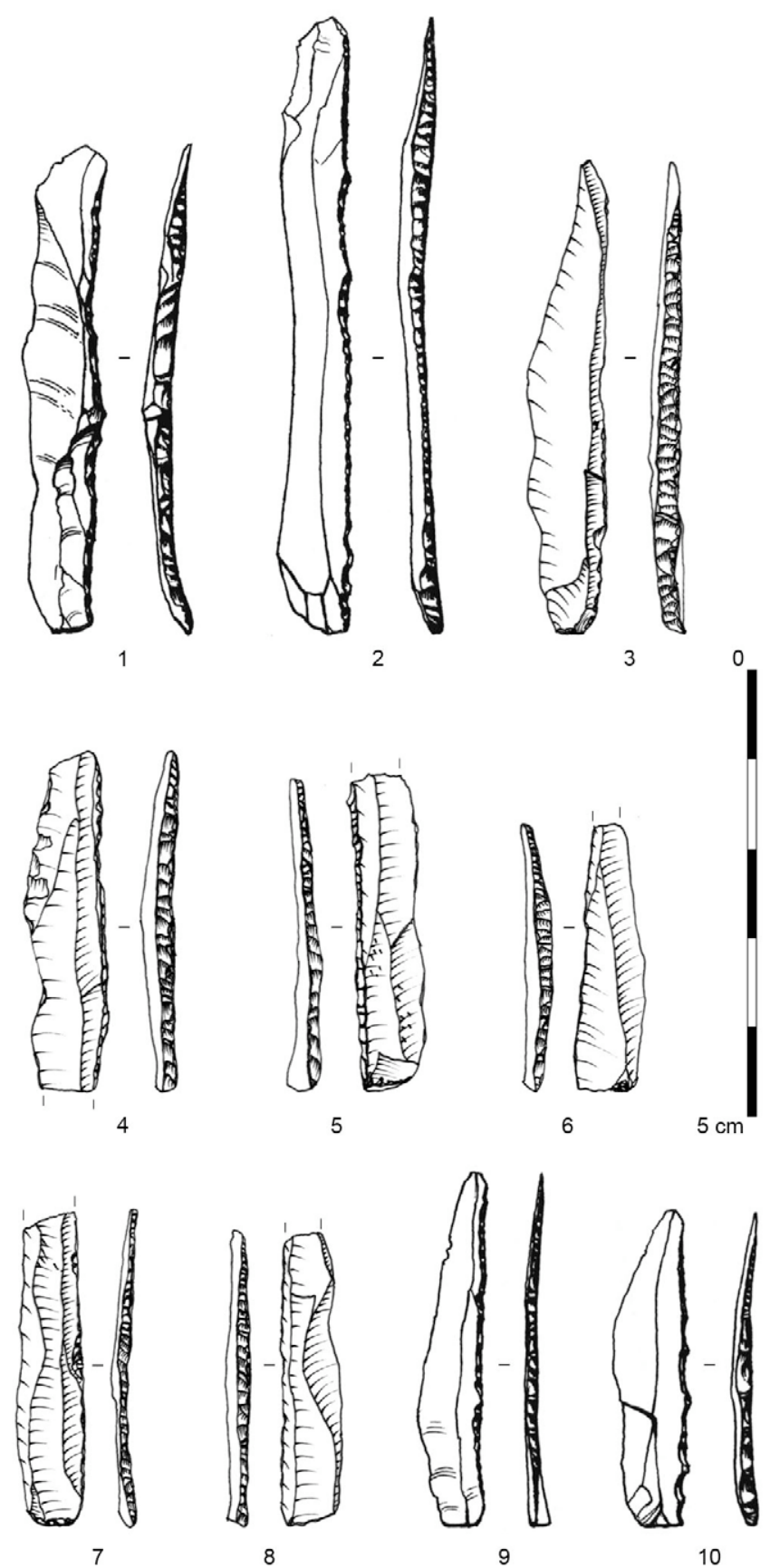

Fig. 4. Examples of backed bladelets from Pincevent, level IV20. 1, 2, 9, 10: drawings R. Humbert in Leroi-Gourhan and Brézillon, 1972. 3 to 8: drawings G. Debout. 

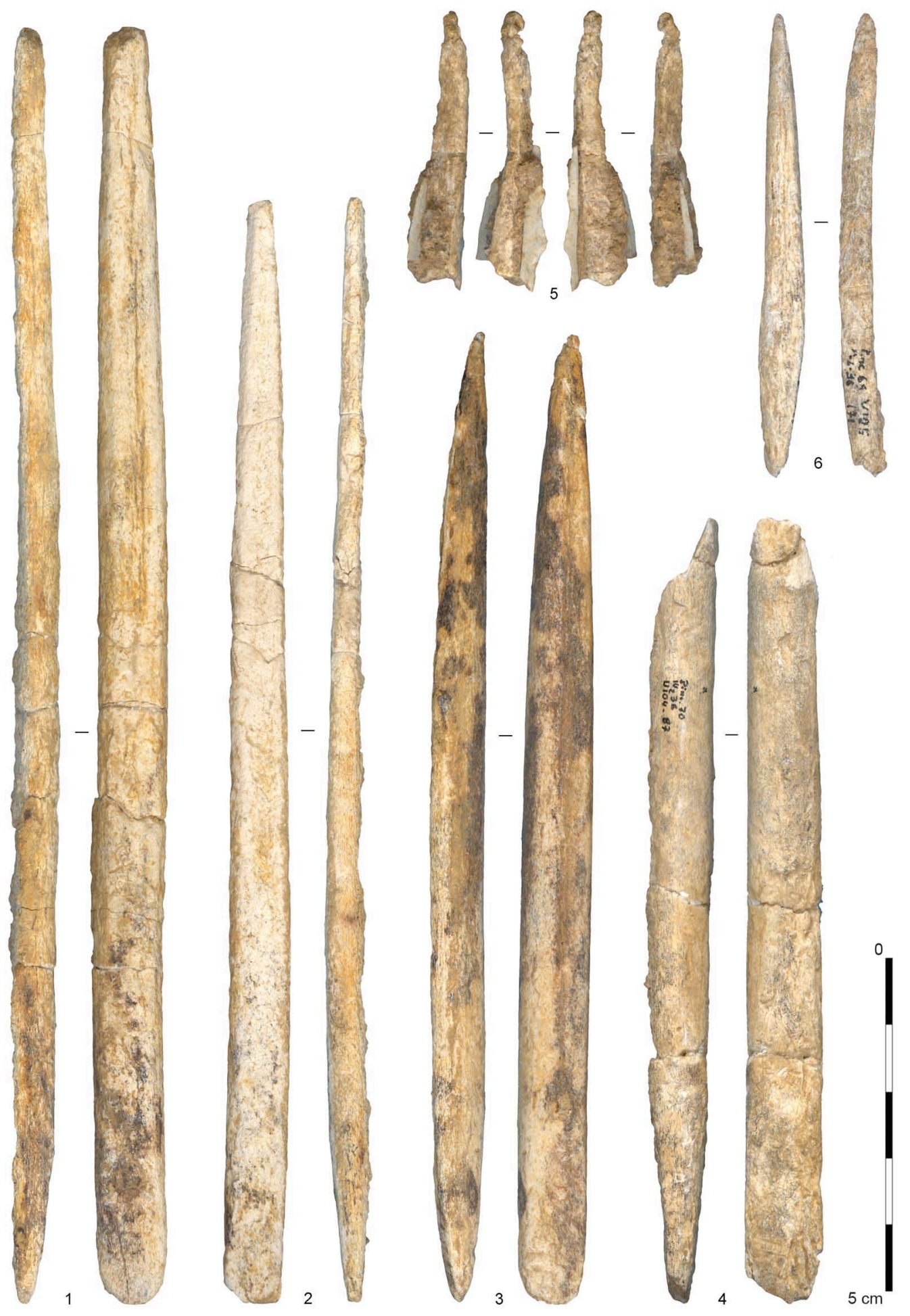

Fig. 5. Examples of antler points from Pincevent, level IV20. 1, 2, 3: nearly complete doublebeveled points (the thickness of specimens 1 and 2 appears reduced because of the poor preservation of the ventral side). 4: mesio-proximal fragment of double-beveled point with distal bending fracture. 5: point fragment with two side-hafted lithic elements. 6: complete double-beveled point (small sub-type). Pictures by M. Vanhaeren/Centre Archéologique de Pincevent. 

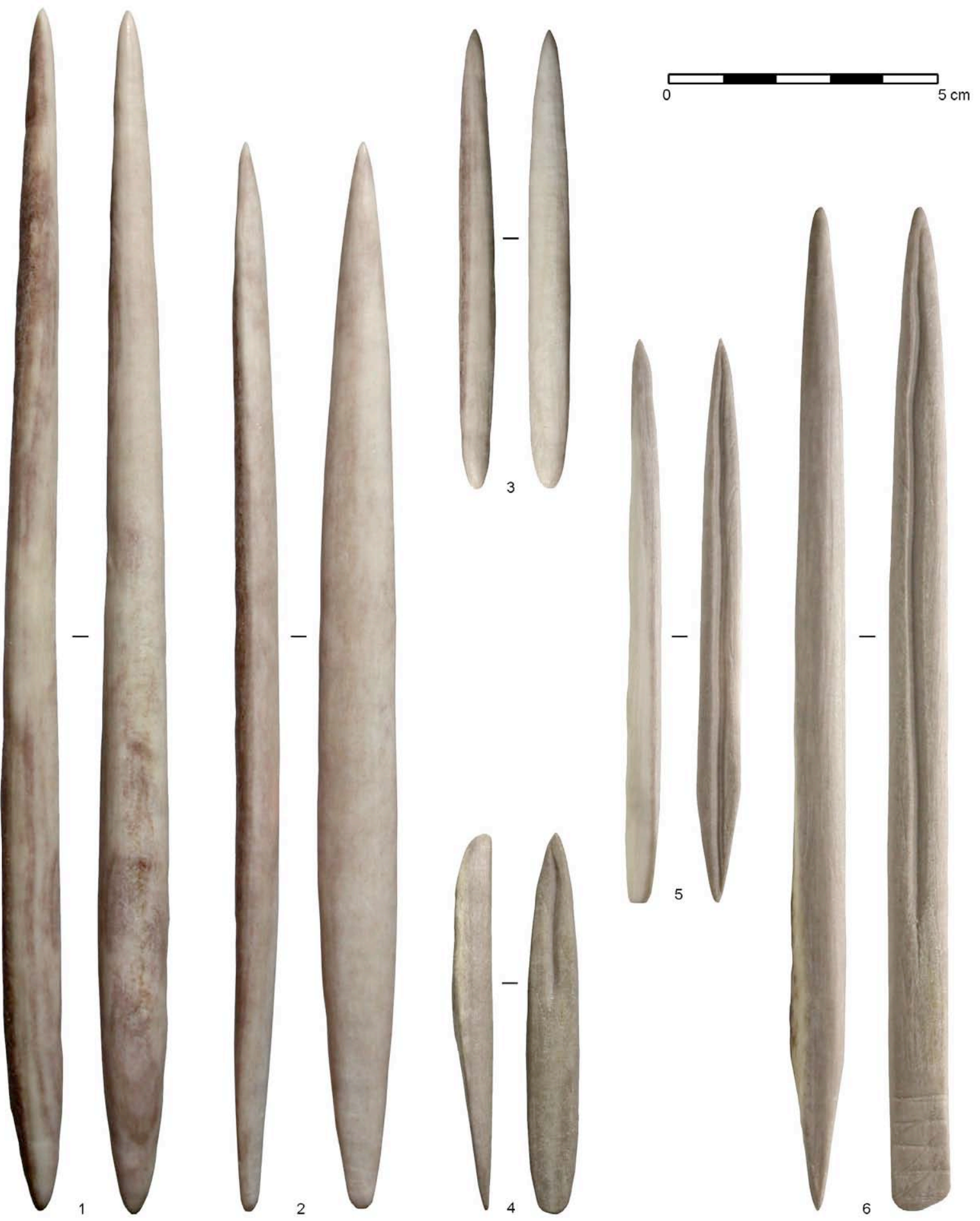

Fig. 6. Sample of experimental antler points. 1, 2, 3: points with massive base, Lower Magdalenian design (1: large and thick; 2: large and thin; 3: small). 4: simple-beveled point. 5, 6: double-beveled points, after the design of Pincevent-IV20 (5: small sub-type; 6: large sub-type). Pictures by J.-M. Pétillon and C. Guéret. 

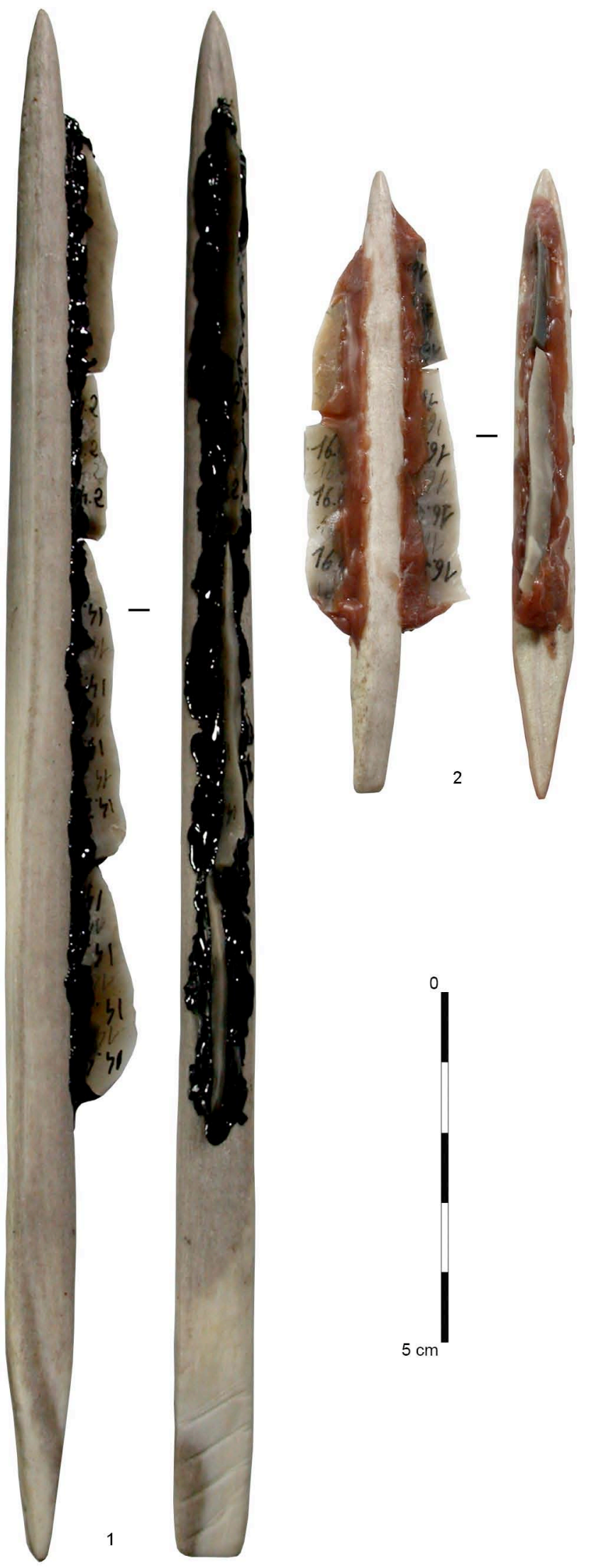

Fig. 7. Experimental composite tips, after the design of Pincevent-IV20. 1: double-beveled point (large sub-type) with one row of bladelets. 2: double-beveled point (small sub-type) with two rows of bladelets. Pictures by J.-M. Pétillon and C. Guéret. 


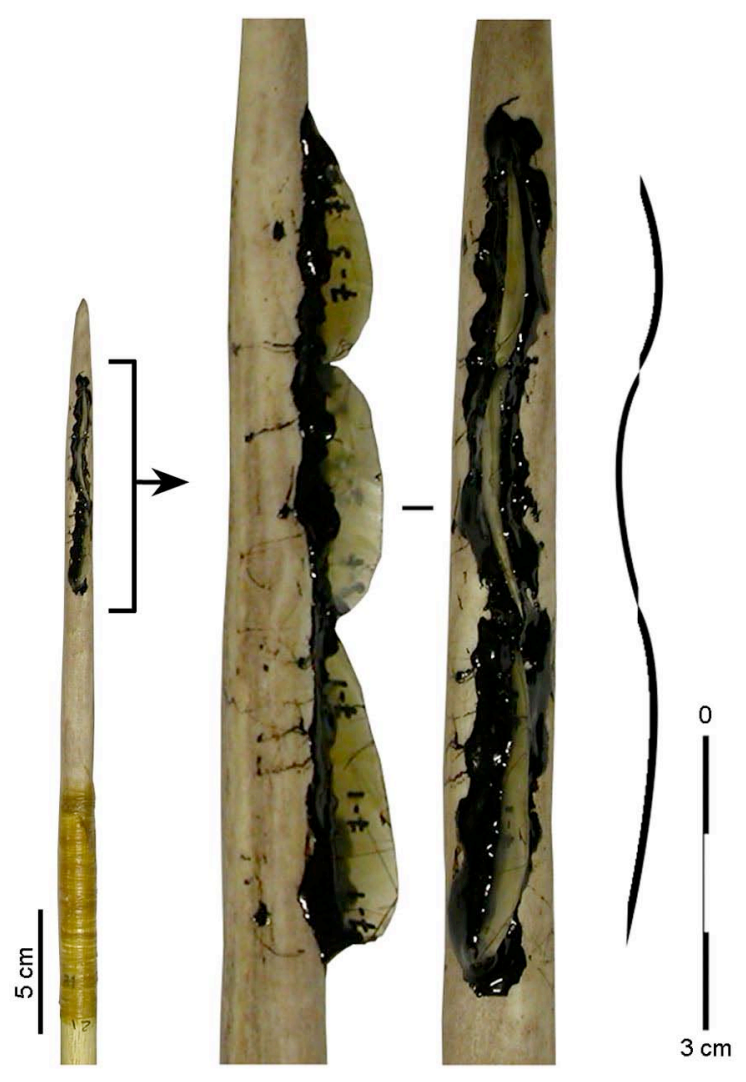

Fig. 8. Experimental composite tip, Lower Magdalenian design; detail of the flint bladelets and their sinuous hafting arrangement. Pictures by M. Langlais. 

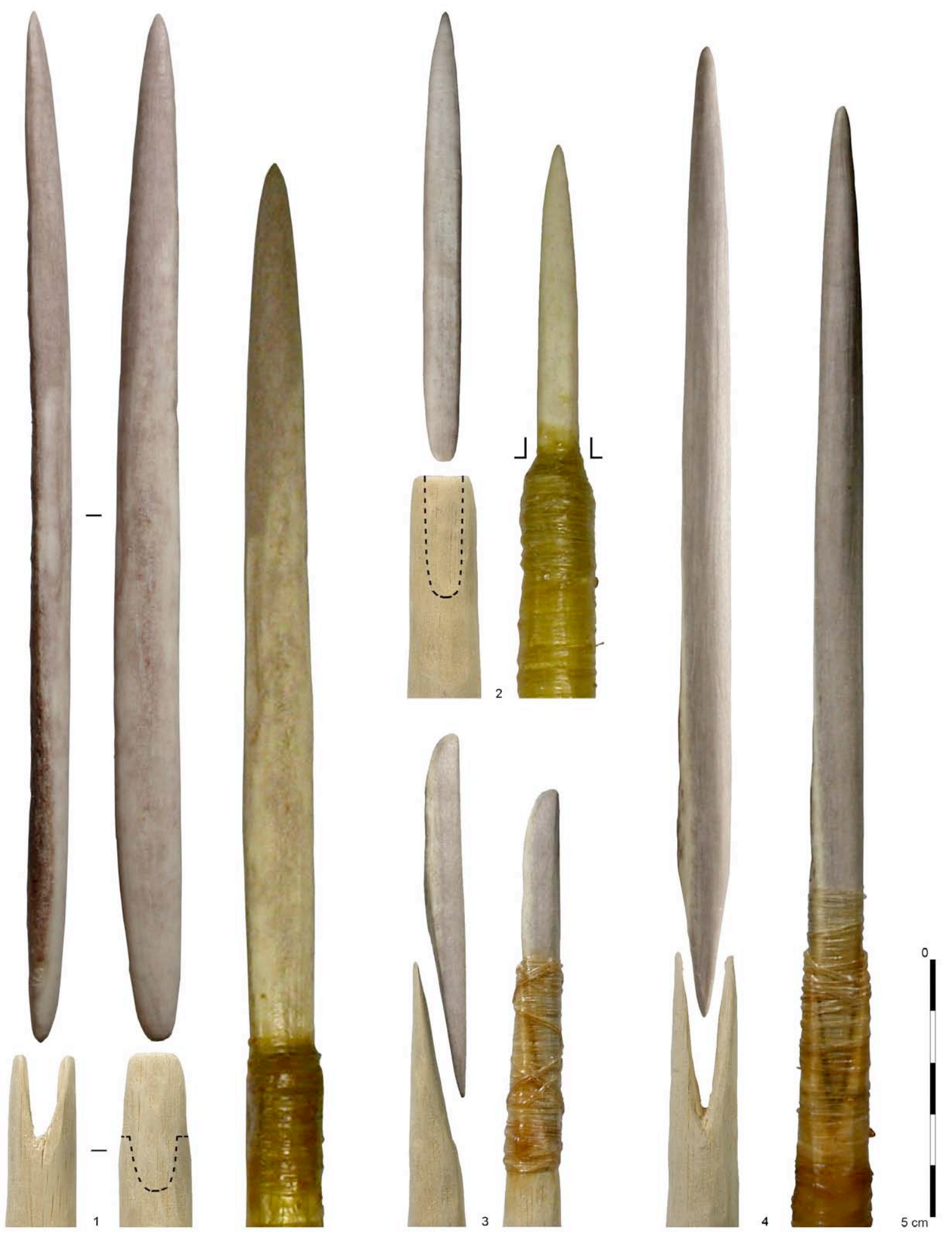

Fig. 9. Hafting and lashing of the experimental points. 1: point with massive base (Lower Magdalenian design, "large and thin" sub-type) hafted in a socket; the lateral openings are intended to avoid the splitting of the shaft. 2: point with massive base (Lower Magdalenian design, small sub-type) hafted in a "closed" socket; with indication of the hilt effect (see text). 3: simple-beveled point. 4: double-beveled point (Pincevent-IV20 design, large sub-type). Pictures by M. Langlais, J.-M. Pétillon and C. Guéret. 


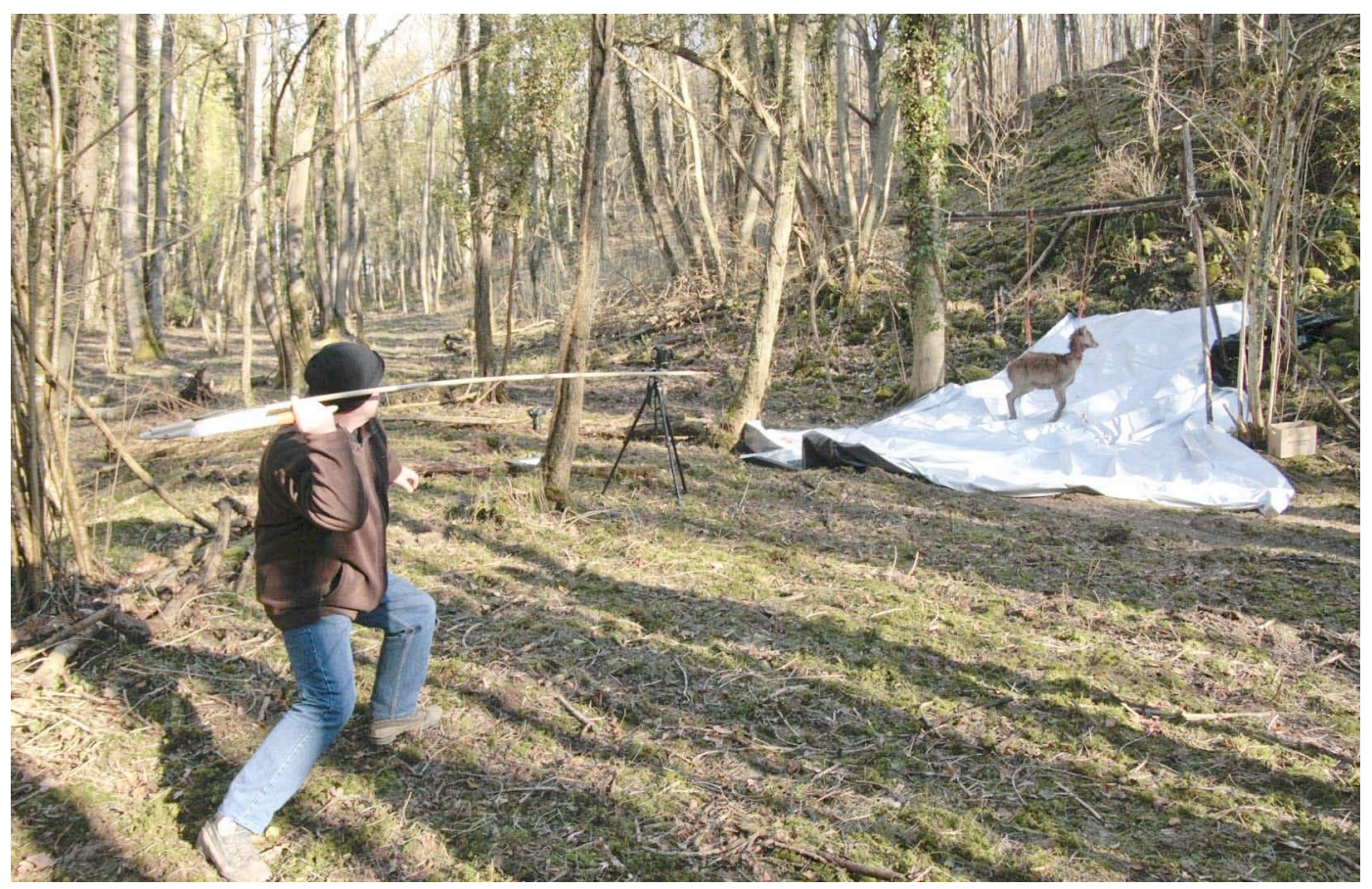

Fig. 10. General view of the experimental setting. P. Chauvaux is about to throw a spear at the target animal. Picture by E. Demoulin. 

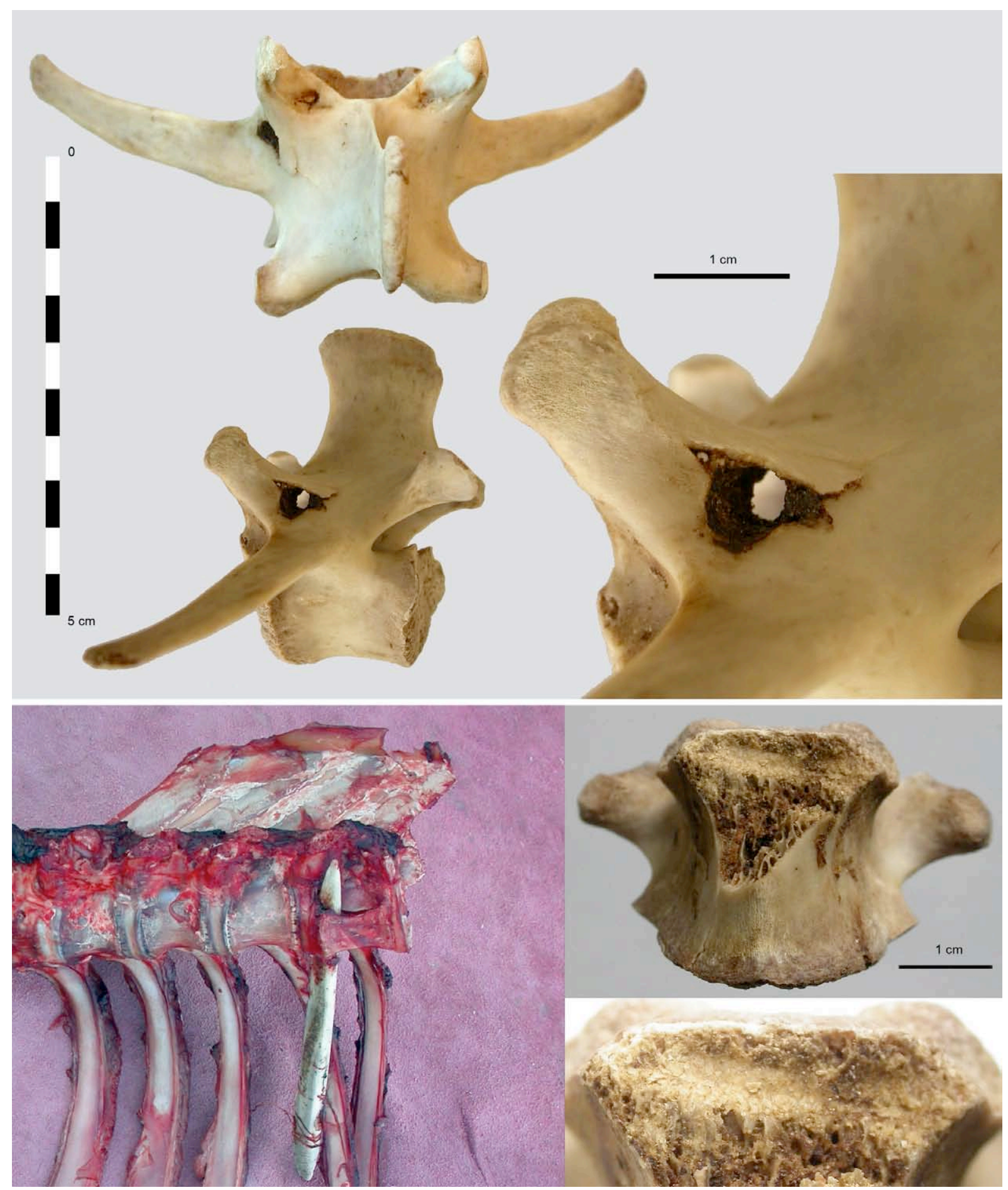

Fig. 11. Perforation damage caused to vertebrae by spear impacts. Top: lumbar vertebra; dorsal view, lateral view and detail. Bottom left: spear point embedded in the body of a thoracic vertebra; bottom right: detail of the perforation canal. Pictures by V. Laroulandie. 


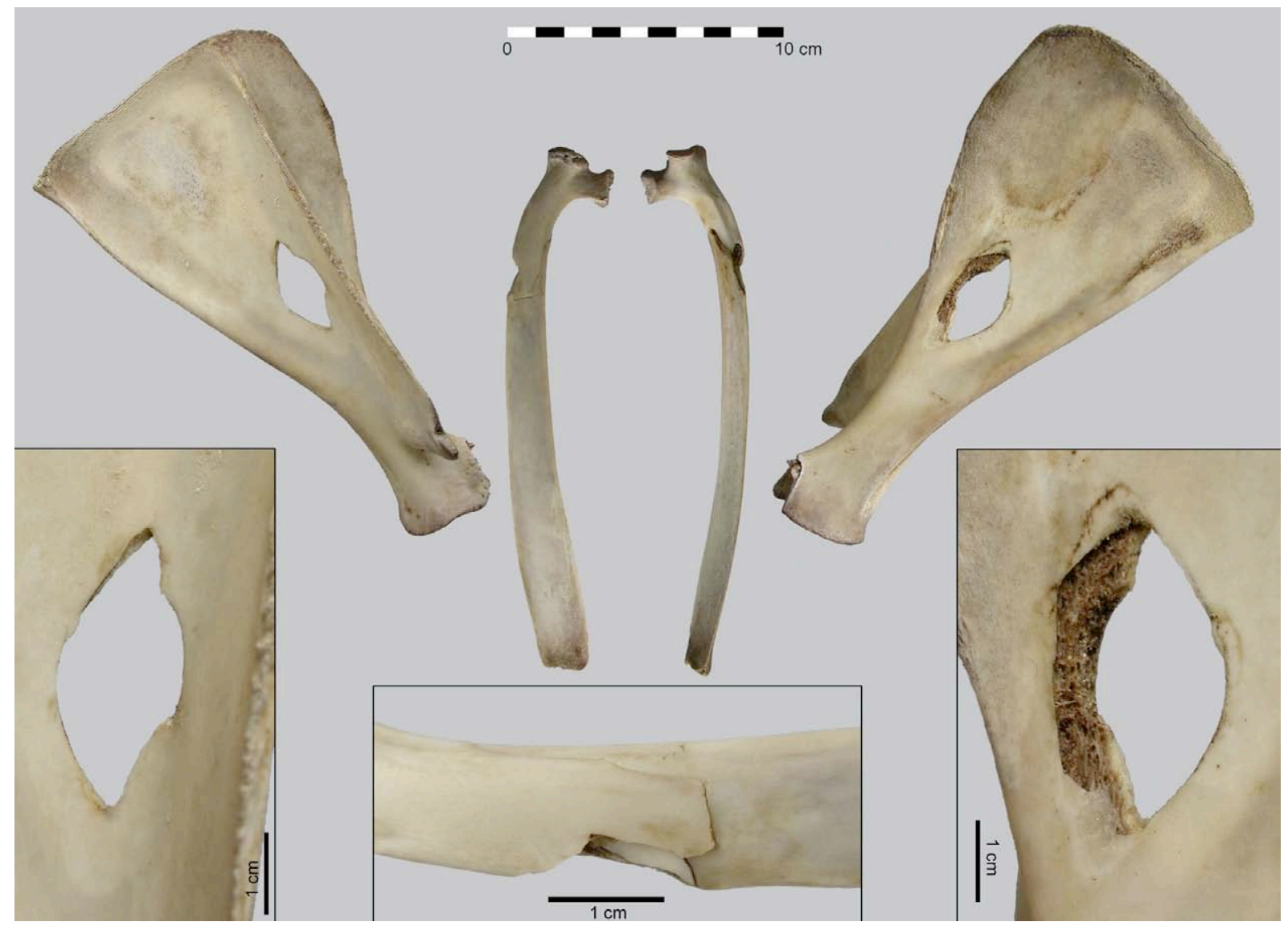

Fig. 12. Left scapula and rib damaged by a single spear impact. Left: lateral view; right: medial view; bottom: detailed view of the perforation (in the scapula) and the notch with cracks (on the rib). Pictures by V. Laroulandie. 


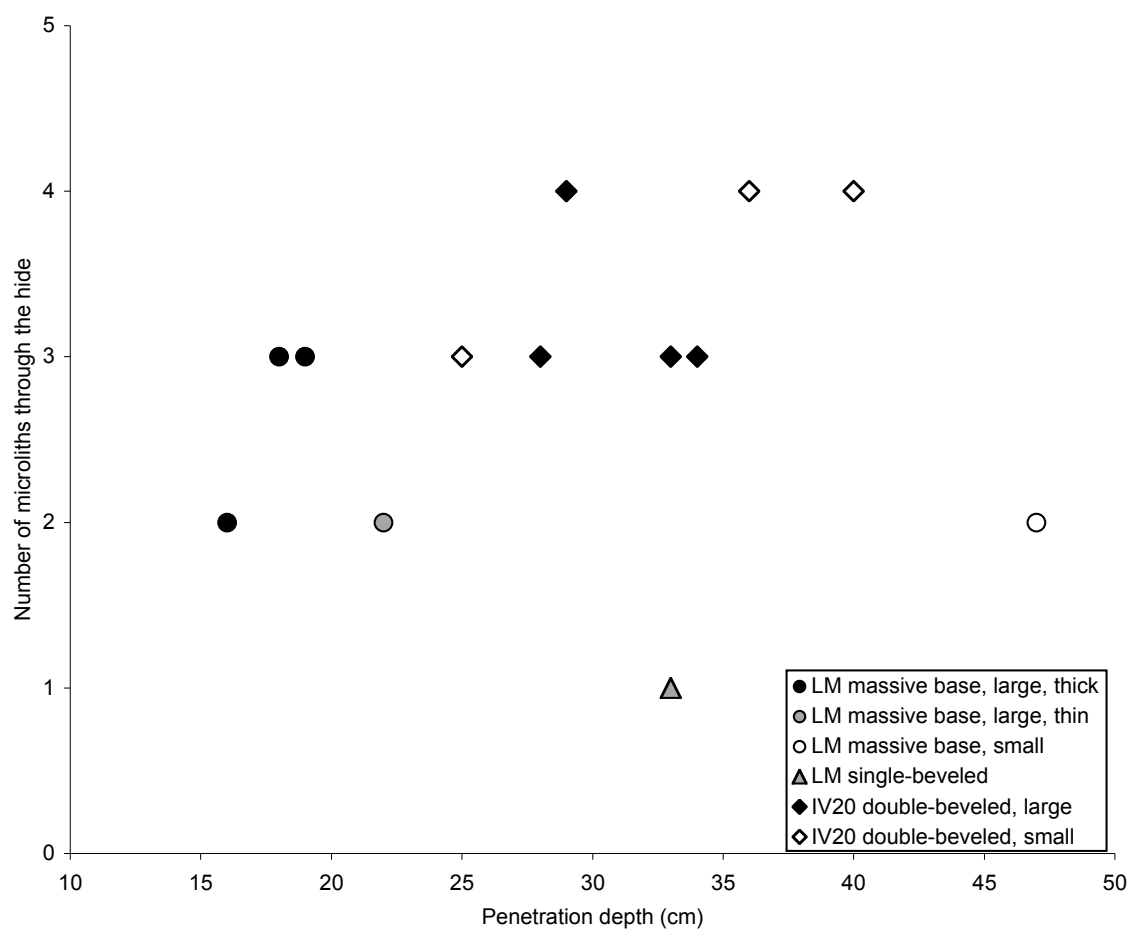

Fig. 13. Plot of penetration depth against the number of microliths that passed through the hide, for hits where at least one microlith managed to penetrate the target's body. One hit was excluded from the graph because the exact number of penetrating microliths could not be documented (one microlith was recovered inside the animal and the two others were lost); a second hit was excluded because the projectile pierced through the scapula and the rib behind it (Fig. 12), which probably caused a drag and reduced penetration. The R2 value (coefficient of determination) is 0.016 for the complete sample ( 13 hits), but 0.507 when excluding the two outlying values at the bottom right. 


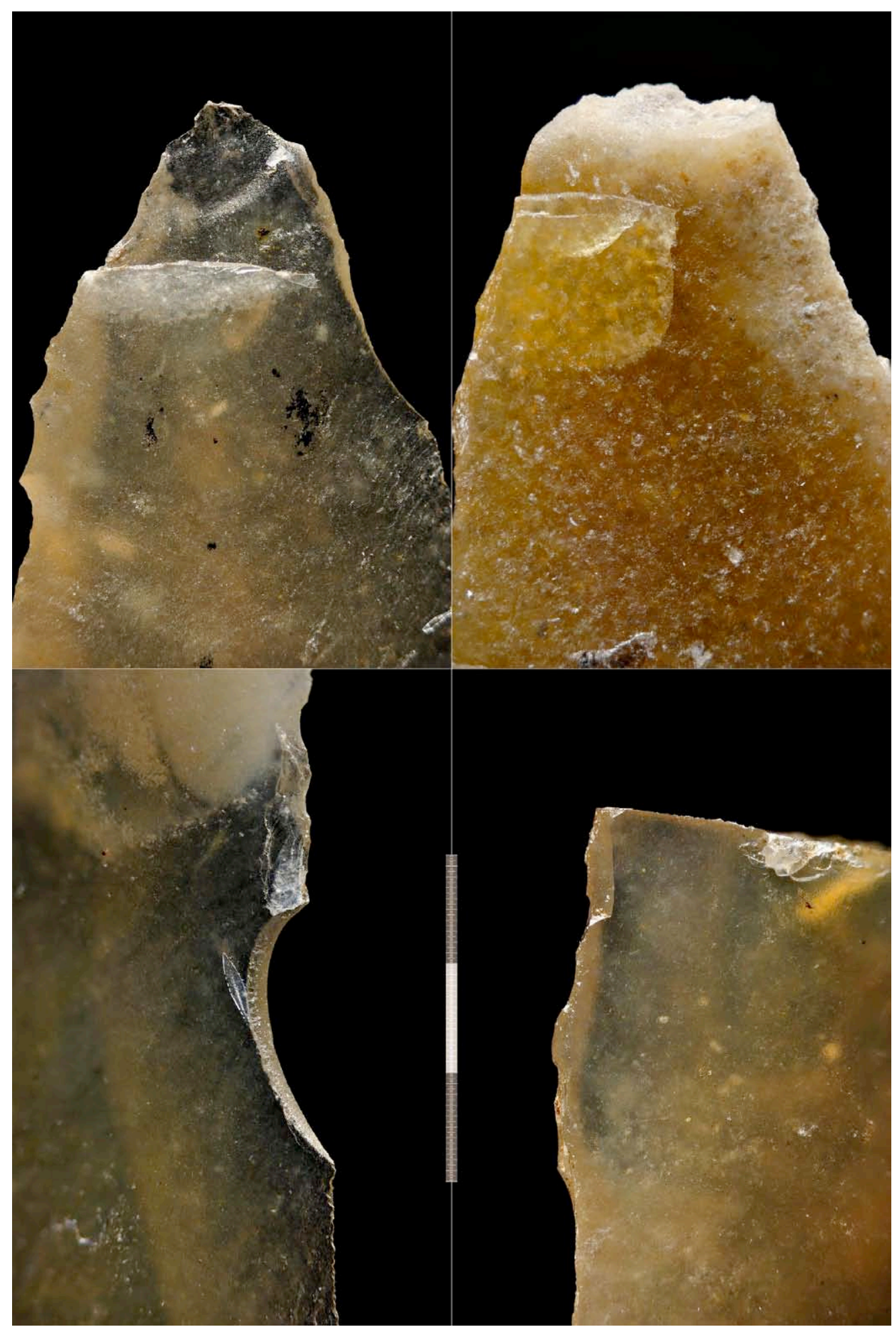

Fig. 14. Examples of the most impacted specimens among the experimental bladelets of Lower Magdalenian design. The four bladelets show diagnostic features of use as projectile inserts, but of very small dimension (scale $=3 \mathrm{~mm}$ ): step terminating bending fracture (top left), spin-off fracture with tip crushing (top right), asymmetric notch (bottom left), transversal snap and impact burination (bottom right). Pictures by H. Plisson. 


\begin{tabular}{|c|c|c|c|c|c|c|c|c|c|c|c|c|c|c|}
\hline \multirow{2}{*}{$\begin{array}{c}\text { Arch. } \\
\text { ref. }\end{array}$} & \multirow[t]{2}{*}{ Base type } & \multirow[t]{2}{*}{ Sub-type } & \multirow[t]{2}{*}{ Number } & \multicolumn{2}{|c|}{ Mass (g) } & \multicolumn{2}{|c|}{ Length } & \multicolumn{2}{|c|}{$\begin{array}{l}\text { Max. } \\
\text { width }\end{array}$} & \multicolumn{2}{|c|}{$\begin{array}{c}\text { Max. } \\
\text { thickness }\end{array}$} & \multicolumn{2}{|c|}{$\begin{array}{c}\text { Comp. } \\
\text { thickness }\end{array}$} & \multirow[t]{2}{*}{ Cross-section } \\
\hline & & & & mean & SD & mean & SD & mean & SD & mean & SD & mean & SD & \\
\hline LM & Massive & large, thick & 4 & 27.7 & 4.7 & 230.5 & 2.6 & 12.3 & 0.2 & 10.9 & 0.9 & 8.3 & 1.9 & circular \\
\hline LM & Massive & large, thin & 4 & 22.0 & 1.3 & 209.8 & 4.3 & 13.9 & 0.6 & 7.9 & 0.3 & 6.0 & 0.9 & oval \\
\hline LM & Massive & small & 4 & 5.1 & 1.3 & 87.6 & 10.1 & 8.0 & 0.6 & 6.5 & 0.6 & 6.4 & 0.6 & oval \\
\hline LM & Single-beveled & NA & 4 & 4.9 & 0.4 & 72.0 & 1.7 & 8.9 & 0.5 & 7.3 & 0.6 & 6.9 & 0.5 & quadrang. \\
\hline IV20 & Double-beveled & large & 12 & 17.5 & 4.8 & 182.2 & 27.3 & 11.2 & 0.6 & 8.5 & 1.1 & 6.7 & 1.5 & quadrang. \\
\hline IV20 & Double-beveled & small & 6 & 5.0 & 0.9 & 92.6 & 11.0 & 8.2 & 0.4 & 6.0 & 0.5 & 5.5 & 0.9 & quadrang. \\
\hline
\end{tabular}

Table 1. Experimental antler points. In this table and in all others, all dimensions are in millimeters; arch. ref.: archaeological reference; comp. thickness: thickness of compact tissue; SD: standard deviation; LM: Lower Magdalenian; IV20: Pincevent, level IV20.

\begin{tabular}{|c|c|c|c|c|c|c|c|c|c|}
\hline \multirow{2}{*}{$\begin{array}{c}\text { Arch. } \\
\text { ref. }\end{array}$} & \multirow{2}{*}{ Number } & \multicolumn{2}{|c|}{ Mass (g) } & \multicolumn{2}{c|}{ Length } & \multicolumn{2}{c|}{ Max. width } & \multicolumn{2}{c|}{ Max. thickness } \\
\cline { 3 - 10 } & & mean & SD & mean & SD & mean & SD & mean & SD \\
\hline LM & 43 & 0.3 & 0.2 & 25.7 & 7.2 & 5.8 & 1.1 & 1.5 & 0.4 \\
\hline IV20 & 58 & 0.8 & 0.4 & 30.2 & 9.5 & 8.2 & 1.3 & 2.6 & 0.6 \\
\hline
\end{tabular}

Table 2. Experimental retouched microliths.

\begin{tabular}{|c|c|c|c|c|c|c|c|c|c|c|c|c|c|}
\hline \multirow{2}{*}{$\begin{array}{c}\text { Arch. } \\
\text { ref. }\end{array}$} & \multirow[t]{2}{*}{ Base type } & \multirow[t]{2}{*}{ Sub-type } & \multicolumn{10}{|c|}{ Number of microliths (upper side + lower side of point) } & \multirow{2}{*}{$\begin{array}{l}\text { Total number } \\
\text { of points } \\
4\end{array}$} \\
\hline & & & $0+0$ & $1+0$ & $1+2$ & $2+0$ & $2+2$ & $3+0$ & $3+2$ & $4+0$ & $4+2$ & $4+4$ & \\
\hline LM & Massive & large, thick & 1 & & & & & 3 & & & & & 4 \\
\hline LM & Massive & large, thin & 1 & & & & & 3 & & & & & 4 \\
\hline LM & Massive & small & 1 & & & 3 & & & & & & & 4 \\
\hline LM & Single-beveled & NA & 1 & 3 & & & & & & & & & 4 \\
\hline IV20 & Double-beveled & large & 4 & & & & & 3 & 1 & 3 & & 1 & 12 \\
\hline IV20 & Double-beveled & small & 2 & & 1 & & 2 & & & & 1 & & 6 \\
\hline
\end{tabular}

Table 3. Number of microliths initially hafted to the antler points. Read as follows: of the 4 small points with massive base (Lower Magdalenian design), 1 was left without microliths, and the other 3 were equipped with a row of 2 microliths on the upper side and 0 on the lower side.

\begin{tabular}{|c|c|c|c|c|c|c|c|c|c|}
\hline & \multicolumn{3}{|c|}{ Thorax, thigh muscle } & \multicolumn{3}{|c|}{ Sternum, thoracic vert. } & \multicolumn{3}{|c|}{ All hits } \\
\hline & \multirow{2}{*}{$\begin{array}{c}\text { Number of } \\
\text { hits }\end{array}$} & \multicolumn{2}{|c|}{ Penetration } & \multirow{2}{*}{$\begin{array}{c}\text { Number of } \\
\text { hits }\end{array}$} & \multicolumn{2}{|c|}{ Penetration } & \multirow{2}{*}{$\begin{array}{c}\text { Number of } \\
\text { hits }\end{array}$} & \multicolumn{2}{|c|}{ Penetration } \\
\hline & & mean & \begin{tabular}{|l|} 
SD \\
\end{tabular} & & mean & SD & & mean & SD \\
\hline Bare points & 8 & 155 & 32.0 & 0 & NA & NA & 8 & 155 & 32.0 \\
\hline Stripped points & 2 & 135 & 5.0 & 3 & 140 & 8.2 & 5 & 138 & 7.5 \\
\hline Bare points + stripped points & 10 & 151 & 29.8 & 3 & 140 & 8.2 & 13 & 148 & 26.8 \\
\hline Points with bladelet(s) & 12 & 276 & 92.0 & 2 & 325 & 75.0 & 14 & 283 & 91.4 \\
\hline
\end{tabular}

Table 4. Penetration depth for all successful hits. "Bare points" were initially hafted without bladelets; "stripped points" are points whose bladelets failed to penetrate the target's hide. One of the 15 hits made by points with bladelets was excluded from the calculation because the projectile pierced through the scapula and the rib behind it (Fig. 12), which probably caused a drag and reduced penetration. The values for "all hits without bladelets" $(n=13)$ and for "all hits with bladelets" $(\mathrm{n}=14)$ are normally distributed (Shapiro-Wilk normality test), and the difference in means between the two populations is statistically highly significant (two-tailed t-test: $\mathrm{t}=5.07, \mathrm{df}=15.399, p$-value $=0.0001273$, equal variance not assumed). 


\begin{tabular}{|l|l|c|c|}
\hline \multicolumn{1}{|c|}{ Type } & \multicolumn{1}{|c|}{ Location } & LM bladelets & IV20 bladelets \\
\hline Notch & cutting edge & 2 & 4 \\
\hline Bending fracture & tip & $2 *$ & 0 \\
\hline Snap + burination & $\begin{array}{l}\text { transversal + cutting edge (LM) } \\
\text { transversal + back (IV20) }\end{array}$ & 1 & 1 \\
\hline Snap & transversal & 0 & 1 \\
\hline Burination & cutting edge & 0 & 1 \\
\hline \multicolumn{2}{|c|}{ TOTAL } & 5 & 7 \\
\hline
\end{tabular}

Table 5. Macroscopic damage observed on the experimental bladelets. *: on one of the bladelets, the fracture exhibits tip crushing. 